\title{
Cytotoxicity and genotoxicity of nano - and microparticulate copper oxide: role of solubility and intracellular bioavailability
}

\author{
Annetta Semisch, Julia Ohle, Barbara Witt and Andrea Hartwig ${ }^{*}$
}

\begin{abstract}
Background: Nano- or microscale copper oxide particles (CUO NP, CuO MP) are increasingly applied as catalysts or antimicrobial additives. This increases the risk of adverse health effects, since copper ions are cytotoxic under overload conditions.

Methods: The extra- and intracellular bioavailability of CuO NP and CuO MP were explored. In addition, different endpoints related to cytotoxicity as well as direct and indirect genotoxicity of the copper oxides and copper chloride $\left(\mathrm{CuCl}_{2}\right)$ were compared.

Results: Comprehensively characterized CUO NP and CuO MP were analysed regarding their copper ion release in model fluids. In all media investigated, CuO NP released far more copper ions than CuO MP, with most pronounced dissolution in artificial lysosomal fluid. $\mathrm{CuO} \mathrm{NP}$ and $\mathrm{CuCl}_{2}$ caused a pronounced and dose dependent decrease of colony forming ability (CFA) in A549 and HeLa S3 cells, whereas CuO MP exerted no cytotoxicity at concentrations up to $50 \mu \mathrm{g} / \mathrm{mL}$. Cell death induced by CuO NP was at least in part due to apoptosis, as determined by subdiploid DNA as well as via translocation of the apoptosis inducing factor (AIF) into the cell nucleus. Similarly, only CuO NP induced significant amounts of DNA strand breaks in HeLa S3 cells, whereas all three compounds elevated the level of $\mathrm{H}_{2} \mathrm{O}_{2}$-induced DNA strand breaks. Finally, all copper compounds diminished the $\mathrm{H}_{2} \mathrm{O}_{2}$-induced poly(ADP-ribosyl) ation, catalysed predominantly by poly(ADP-ribose)polymerase-1 (PARP-1); here, again, CuO NP exerted the strongest effect. Copper derived from $\mathrm{CuO} \mathrm{NP}, \mathrm{CuO} \mathrm{MP}$ and $\mathrm{CuCl}_{2}$ accumulated in the soluble cytoplasmic and nuclear fractions of A549 cells, yielding similar concentrations in the cytoplasm but highest concentrations in the nucleus in case of CuO NP.
\end{abstract}

Conclusions: The results support the high cytotoxicity of $\mathrm{CuONP}$ and $\mathrm{CuCl}_{2}$ and the missing cytotoxicity of CuO MP under the conditions applied. For these differences in cytotoxicity, extracellular copper ion levels due to dissolution of particles as well as differences in physicochemical properties of the particles like surface area may be of major relevance. Regarding direct and indirect genotoxicity, especially the high copper content in the cell nucleus derived after cell treatment with CuO NP appears to be decisive.

Keywords: Copper oxide nanoparticles, Copper oxide microparticles, Copper chloride, Bioavailability, Intracellular distribution, Cytotoxicity, Genotoxicity, Poly(ADP-ribosyl)ation, Apoptosis

\footnotetext{
* Correspondence: andrea.hartwig@kit.edu

Department of Food Chemistry and Toxicology, Karlsruhe Institute of

Technology (KIT), Institute for Applied Biosciences, Adenauerring 20a,

Karlsruhe 76131, Germany
}

\section{Biomed Central




\section{Background}

The transition metal copper is an essential trace element and a catalytic cofactor in more than 30 enzymes $[1,2]$. Under physiological conditions, the cellular copper homeostasis is tightly regulated [3]. However, under overload conditions copper is potentially toxic: Due to its redox activity copper catalyzes Fenton-type reactions, generating the highly reactive hydroxyl radical, which may damage cellular components like proteins, nucleic acids or membrane lipids [4]. Furthermore, due to its high affinity towards thiols, copper may bind to and/or oxidize redox-sensitive amino acids like cysteines, thereby destroying redox-sensitive protein structures. This may also include proteins or enzymes with zinc-binding domains of proteins or enzymes involved in maintaining genomic stability, such as several DNA repair and DNA damage signalling enzymes like PARP-1 [5,6].

Potential conditions for copper overload are supranutritional intake, e.g., due to food supplementation, genetic disorders or inhalation of copper containing fumes or aerosols. With respect to the latter, particulate copper oxides like synthesized $\mathrm{CuO} \mathrm{NP}$ or $\mathrm{CuO} \mathrm{MP}$ are increasingly applied as catalysts, antimicrobial additives or in pigment production [7-10]. Nevertheless, appropriate toxicological examinations of risks and benefits of nanosized materials are still rare. Different to water soluble metal compounds, where the toxicologically relevant interactions depend on the chemical properties of the respective metal ions, the physicochemical characteristics of particles and their interactions with cells additionally affect biological outcomes and underlying mechanisms $[11,12]$. Relevant features are size, morphology, specific surface area and crystallinity, elemental composition as well as solubility in biologically relevant media [13].

The particle characteristics described above will also determine the uptake, intracellular bioavailability and thus the potential toxicity of the respective compounds. While copper ions enter the cell via transporters, nano- and microsized particles may be internalized by endocytosis $[14,15]$, which in case of $\mathrm{CuO} \mathrm{NP}$ has been visualized and confirmed, mainly using transmission electron microscopy (TEM) [16-18]. Once inside the cell, toxicologically relevant reactions will also depend on the release of ions of the respective material in different cellular compartments including the lysosomes and subsequent concentrations reached in the cytoplasm and in the cell nucleus.

$\mathrm{Cu}$-based nanoparticles have been shown to be particularly cyto- and genotoxic, both, when compared to other metal-based nanoparticles or when compared to copperbased microsize particles $[19,20]$. Also, with respect to genotoxicity, $\mathrm{CuO} \mathrm{NP}$ induced DNA damage to a greater extent than $\mathrm{CuO} \mathrm{MP}$ in the comet assay [17,20,21]. Additionally, incubation with $\mathrm{CuO} \mathrm{NP}$ increased the extent of chromosomal damage as determined by micronuclei formation [22-24].
This raises the question on the underlying mechanisms. In principle, toxic reactions could be due to the interaction of the particles with the plasma membrane or with intracellular components. Furthermore, the deliberation of copper ions due to extracellular or intracellular dissolution of the particles could contribute to the observed effects. The aim of the present study was to systematically investigate and compare the toxic and genotoxic potential of well characterized $\mathrm{CuO} \mathrm{NP}, \mathrm{CuO}$ $\mathrm{MP}$ and $\mathrm{CuCl}_{2}$ in A549 and HeLa S3 cells. Special emphasis was given to the extracellular and intracellular bioavailability of copper ions. We determined the dissolution of $\mathrm{CuO} \mathrm{NP}$ and $\mathrm{CuO} \mathrm{MP}$ in model fluids like artificial alveolar fluid (AAF), Dulbecco's Modified Eagle Medium with serum (DMEM/FCS) or without serum (DMEM) as well as in artificial lysosomal fluid (ALF). In a further approach, we determined the bioavailability and intracellular distribution of copper ions in cells. In order to relate these findings to biological effects we examined cytotoxicity, apoptosis, induction of DNA strand breaks and micronuclei formation. Furthermore, we determined the impact on poly(ADP-ribosyl)ation, since this reaction involved in DNA damage signalling has been shown previously to be inhibited by water soluble $\mathrm{CuCl}_{2}$ [6]. Our results demonstrate that especially the increase in nuclear copper concentrations will determine the direct and indirect genotoxicity of the respective copper compounds.

\section{Results}

\section{Particle characterization}

First, the particles were characterized with respect to chemical composition, crystallinity, morphology, endotoxin contamination as well as size, surface area, $\mathrm{pH}$ and Zeta potential (ZP), also in cell culture media. Scanning electron microscopy revealed an approximately spherical and smooth surface of $\mathrm{CuO}$ NP. They exhibited a broad size distribution ranging from approximately $20 \mathrm{~nm}$ to around $200 \mathrm{~nm}$ (Figure 1A). CuO MP appeared rough and irregularly shaped. They were hardly distinguishable as individual particles and seemed to be aggregated or agglomerated consisting of smaller submicron particles. To discriminate between agglomerates and aggregates, particles were treated with an ultrasound tip for $60 \mathrm{~s}$. Since no breakdown of particles was observed (data not shown), they were most likely aggregated. Size reached in some cases more than $10 \mu \mathrm{m}$ (Figure 1B). The specific surface area, as determined by Brunauer-Emmett-Teller (BET) analysis, was around 23 times larger in case of $\mathrm{CuO}$ $\mathrm{NP}\left(17.23 \mathrm{~m}^{2} / \mathrm{g}\right)$ when compared to $\mathrm{CuO} \mathrm{MP}\left(0.74 \mathrm{~m}^{2} / \mathrm{g}\right)$. Calculated average diameters, assuming uniform spherical particles, were $55 \mathrm{~nm}(\mathrm{CuO} \mathrm{NP})$ and $1289 \mathrm{~nm}(\mathrm{CuO} \mathrm{MP})$. These values confirm data provided by the manufacturer (CuO NP: $\leq 50 \mathrm{~nm}, \mathrm{CuO} \mathrm{MP}:<5 \mu \mathrm{m})$. Both substances 

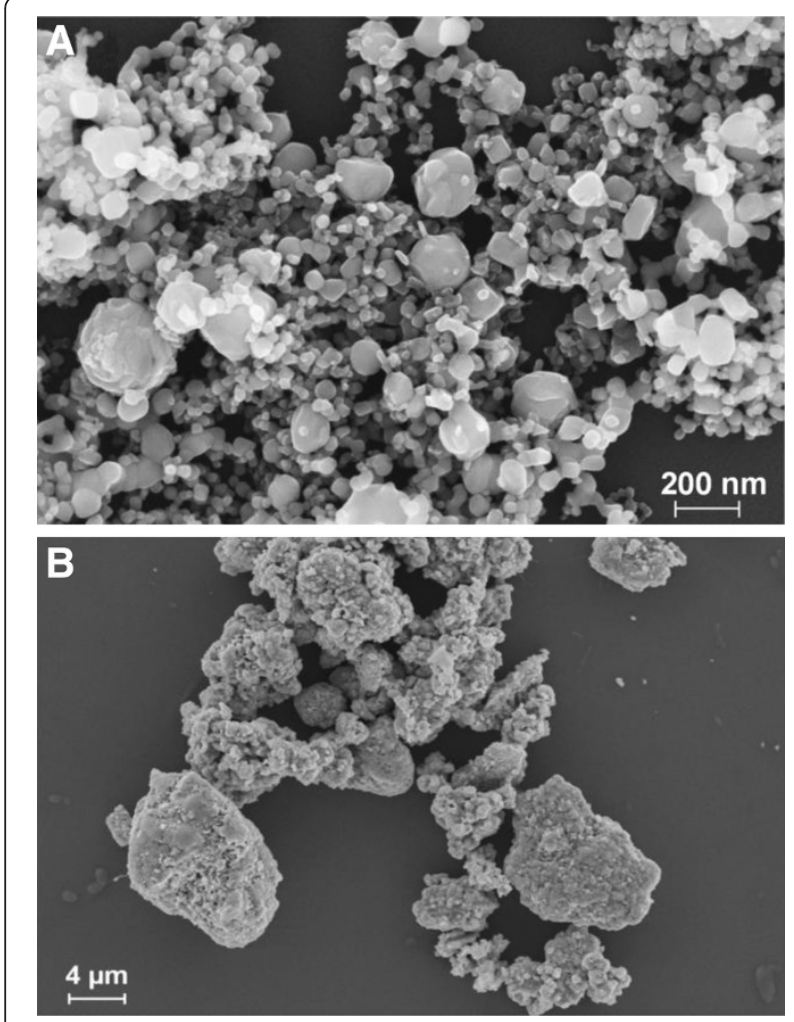

Figure 1 SEM images CuO NP and CuO MP. Images of (A) CuO NP (Magnification $150000 \times$ ) and (B) CuO MP (Magnification $6500 \times$ ) were taken at $10 \mathrm{kV}$ acceleration voltage.

did not alter the $\mathrm{pH}$ of the cell culture medium DMEM/ FCS, were free of endotoxines, of crystalline form and exhibited a purity of $>99.8 \%$ as determined by Inductively coupled plasma mass spectrometry (ICP-MS), analysis of the oxygen content and Energy-dispersive $\mathrm{X}$-ray spectroscopy (EDX) (data not shown). To also define particle characteristics under cell culture conditions, the Dynamic light scattering (DLS) and ZP were determined in ultrapure water $\left(\mathrm{H}_{2} \mathrm{O}\right)$, DMEM and DMEM/FCS using the Zetasizer Nano ZS (Malvern). As a prerequisite to DLS and ZP measurements, the viscosity, diffraction index, density and the dielectricity constants of DMEM and DMEM/ FCS were determined. The viscosity in the presence of salts (DMEM, $1.09 \mathrm{mPas}$ ) and serum (DMEM/FCS, $1.15 \mathrm{mPas}$ ) was slightly increased while the other characteristics resembled those observed in $\mathrm{H}_{2} \mathrm{O}$ (listed in Materials and methods).

Suspended in $\mathrm{H}_{2} \mathrm{O}$, DMEM or DMEM/FCS CuO NP revealed a size distribution centered around a hydrodynamic radius of $488 \mathrm{~nm}, 205 \mathrm{~nm}$ and $146 \mathrm{~nm}$, respectively, indicating the formation of larger agglomerates in the absence of buffer components and serum proteins. The ZP was -14.4 mV (DMEM), - $13.1 \mathrm{mV}$ (DMEM/ FCS) and $-4.5 \mathrm{mV}\left(\mathrm{H}_{2} \mathrm{O}\right)$. Due to rapid sedimentation, the $\mathrm{CuO}$ MP could not be analysed by DLS.

\section{Solubility in model fluids}

Next, the solubility of the particles was investigated in several model fluids. Even though the results are not directly transferable to biological fluids where for example the formation of protein coronas appear to be of major importance, the solubility in different media provide important information on the ratio between particulate and soluble fractions of the respective particles in the experimental system and also some hints on their intracellular fate. Thus, the dissolution of $\mathrm{CuO} \mathrm{MP}$ and $\mathrm{CuO} \mathrm{NP}$ was quantified in $\mathrm{H}_{2} \mathrm{O}$, phosphate buffered saline (PBS), DMEM, DMEM/FCS and AAF. Since after endocytosis the particles are located in lysosomes, copper ion release was additionally determined in ALF ( $\mathrm{pH} 4.5)$. After the specified incubation times the supernatants were repeatedly centrifuged and the concentrations of released copper were quantified by graphite furnace atomic absorption spectroscopy (GF-AAS). In $\mathrm{H}_{2} \mathrm{O}$, PBS (data not shown) and AAF, dissolution for both particles types was below $2.4 \%$, with $\mathrm{CuO} N \mathrm{NP}$ releasing more copper ions than $\mathrm{CuO}$ MP (Figure 2A). Nevertheless, dissolution of CuO NP was highly accelerated in a time-dependent manner in cell culture medium (DMEM) supplemented with FCS: Here, after $2 \mathrm{~h}, 14 \%$ of the copper content were solubilized, reaching $44 \%$ after $24 \mathrm{~h}$. In contrast, copper ion release from $\mathrm{CuO} \mathrm{MP}$ remained low with $4 \%$ dissolved copper after $24 \mathrm{~h}$ incubation. In DMEM in the absence of FCS, the solubility was higher for both particle types: $66 \%$ of copper ions were released from $\mathrm{CuO} \mathrm{NP}$ and $27 \%$ from $\mathrm{CuO} \mathrm{MP}$ after $24 \mathrm{~h}$ (Figure $2 \mathrm{~B}$ ). The accelerated solubility of $\mathrm{CuO}$ NP as compared to $\mathrm{CuO} \mathrm{MP}$ was even more pronounced in an acidic environment. Thus, in ALF, $68 \%$ of the $\mathrm{CuO} \mathrm{NP}$ was already solubilized after $30 \mathrm{~min}$, and after $2 \mathrm{~h}$ dissolution was almost complete. In contrast, $\mathrm{CuO} \mathrm{MP}$ revealed only $10 \%$ dissolution after $4 \mathrm{~h}$ and about $80 \%$ solubilization was reached only after $168 \mathrm{~h}$ (Figure 2C).

\section{Cytotoxicity}

To compare the cytotoxicity and to define appropriate incubation conditions for the subsequent experiments, the colony forming abilities (CFA) of A549 and HeLa S3 cells after $24 \mathrm{~h}$ incubation with $\mathrm{CuO} \mathrm{NP}, \mathrm{CuO} \mathrm{MP}$ or $\mathrm{CuCl}_{2}$ were investigated. This approach was chosen since nanoparticles and metals ions may interfere with frequently applied dye-based toxicity assays. In case of copper, $\mathrm{CuO} \mathrm{NP}$ and $\mathrm{CuCl}_{2}$ were observed to interfere with the reduction of [2-(2-methoxy-4-nitrophenyl)-3-(4nitrophenyl)-5-(2,4-disulfophenyl)-2H-tetrazolium, monosodium salt] (WST-8) to the corresponding formazan [25]. In A549 cells, strongest dose-dependent cytotoxicity was seen in case of $\mathrm{CuO} \mathrm{NP}$, followed by $\mathrm{CuCl}_{2}$. Thus, after $24 \mathrm{~h}$ incubation, a significant decrease was observed for $\mathrm{CuONP}$ at $5 \mu \mathrm{g} / \mathrm{mL}$, with a residual viability below 


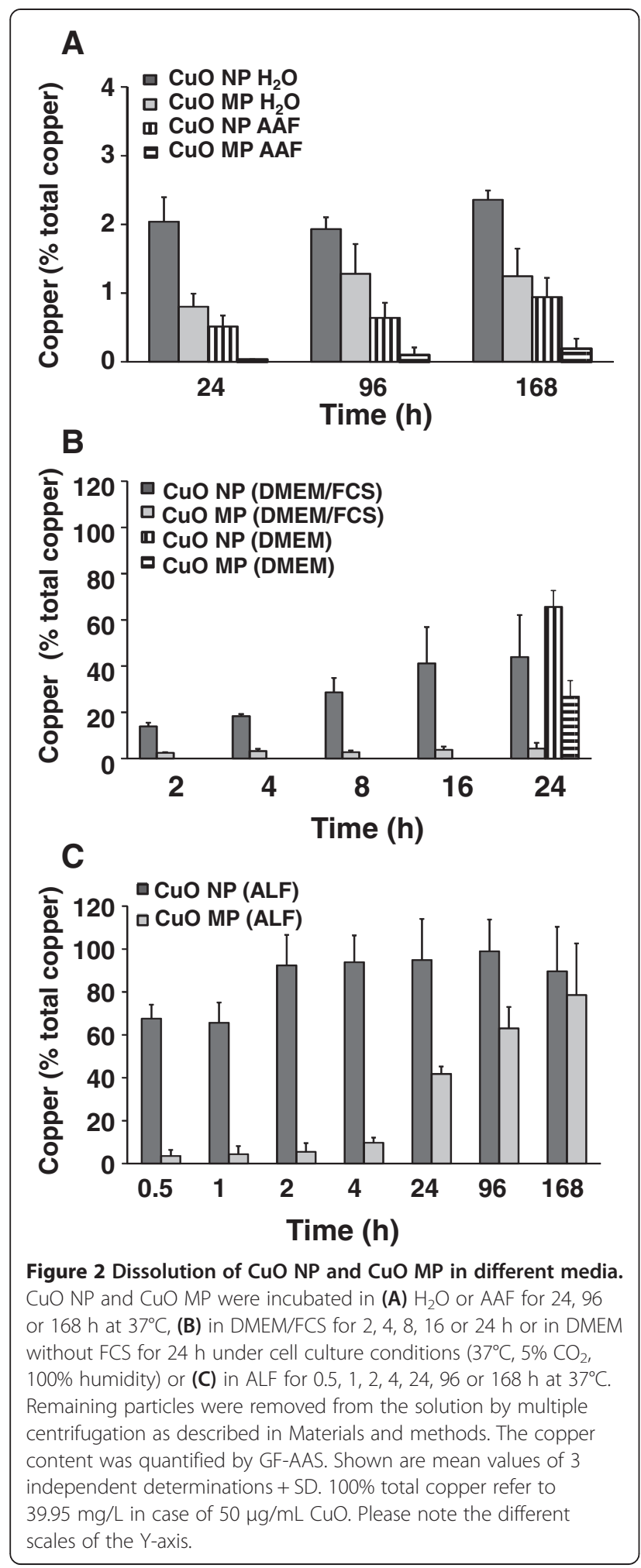

$10 \%$ CFA at the highest concentration of $50 \mu \mathrm{g} / \mathrm{mL}$. Based on the copper content, cytotoxicity of $\mathrm{CuCl}_{2}$ was similar at low concentrations, but less toxicity was seen at higher concentrations. Surprisingly, $\mathrm{CuO} \mathrm{MP}$ were not cytotoxic over the whole concentration range (Figure 3A). Similar effects were evident in HeLa S3 cells: While again $\mathrm{CuO}$ $\mathrm{MP}$ were not cytotoxic, in this case $\mathrm{CuO} \mathrm{NP}$ and $\mathrm{CuCl}_{2}$ led to comparable reduction in CFA, based on the total copper content of the two compounds (Figure 3B). Due to the high cytotoxicity of $\mathrm{CuO} \mathrm{NP}$ and $\mathrm{CuCl}_{2}$, the subsequent experiments were conducted with particle concentrations up to $20 \mu \mathrm{g} / \mathrm{mL} \mathrm{CuO}$ or $252 \mu \mathrm{M} \mathrm{CuCl}_{2}$, respectively, except for investigations on apoptosis and the induction of micronuclei.

\section{Apoptosis}

To investigate whether the cytotoxicity is due to apoptosis, three different parameters were analysed in A549 cells, namely the translocation of the apoptosis inducing factor (AIF) into the cell nucleus, the impact of the copper compounds on caspase 3 and 7 activities as well as the accumulation of subdiploid DNA, detected as a subG1 peak via flow cytometry.

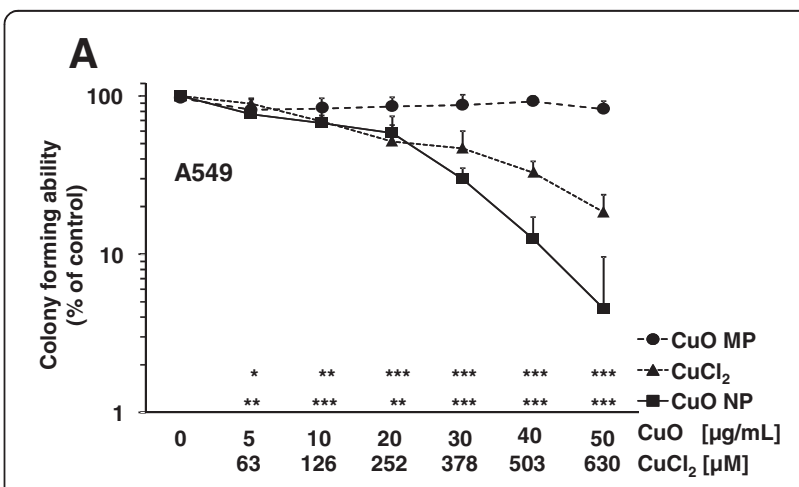

B

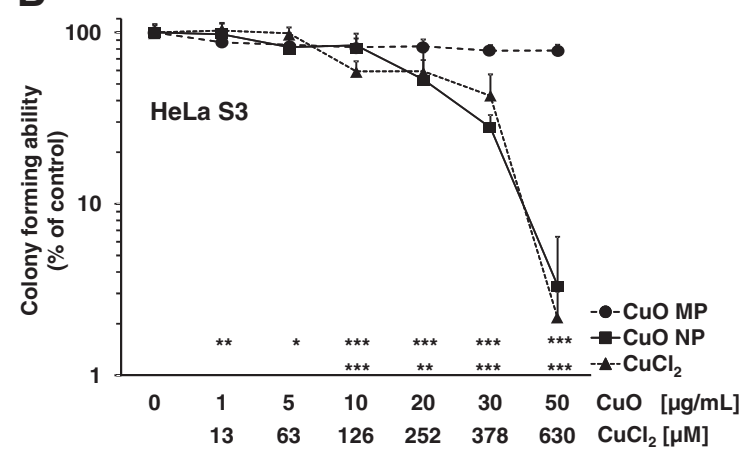

Figure 3 Cytotoxicity of $\mathrm{CuO} \mathrm{NP}, \mathrm{CuO} \mathrm{MP}$ and $\mathrm{CuCl}_{2}$. Cytotoxicity was determined by colony forming ability (CFA). Logarithmically growing (A) A549 or (B) HeLa S3 cells were treated with CuO NP, CuO MP or $\mathrm{CuCl}_{2}$ for $24 \mathrm{~h}$, trypsinized, counted and reseeded. Shown are mean values of at least 9 determinations + SD. Statistically different from control cells: ${ }^{*} p<0.05,{ }^{* *} p<0.01,{ }^{* * *} p<0.001$ as determined by unifactorial analysis of variance (ANOVA) followed by Dunnett's T3 test. $1 \mu \mathrm{g} / \mathrm{mL}$ are equal to $0.2 \mu \mathrm{g} / \mathrm{cm}^{2}$ and $50 \mu \mathrm{g} / \mathrm{mL} \mathrm{CuO}$ are equal to $630 \mu \mathrm{M} \mathrm{Cu}^{2+}$ in case of complete dissolution. 


\section{Translocation of AIF}

To investigate the intracellular localization of AIF in A549 cells after exposure to $\mathrm{CuO} \mathrm{NP}, \mathrm{CuO} \mathrm{MP}$ or $\mathrm{CuCl}_{2}$, fluorescence-labelled antibodies were applied and the cellular location of AIF was determined by fluorescence microscopy. After $8 \mathrm{~h}, 16 \mathrm{~h}$ or $24 \mathrm{~h}$ incubation with $\mathrm{CuO} \mathrm{NP}$, a slight concentration-dependent increase of AIF translocation in the cell nucleus was observed, resulting in 1.29, 1.33 and 1.52 fold fluorescence values $(40 \mu \mathrm{g} / \mathrm{mL} \mathrm{CuO} \mathrm{NP})$ over the control, respectively. In contrast, $\mathrm{CuO} \mathrm{MP}$ and $\mathrm{CuCl}_{2}$ caused no AIF translocation into the cell nucleus at any time point investigated. The results after $24 \mathrm{~h}$ are presented in Figure 4A. The positive control staurosporine enhanced the control fluorescence to the 2.21, 2.33 and 2.17 fold values after 8,16 or $24 \mathrm{~h}$, respectively.



\section{Impact on caspase 3/7 activity}

An alteration in the activity of the effector caspases 3 or 7 after 24 h incubation with $\mathrm{CuO} \mathrm{NP}, \mathrm{CuO} \mathrm{MP}$ or $\mathrm{CuCl}_{2}$ was analysed by applying a luciferase-based assay as described in Materials and methods. None of the copper compounds affected caspase 3 or caspase 7 activities in A549 cells (data not shown). The positive control staurosporine increased the caspase activities 8.7-fold.

\section{Accumulation of sub-diploid DNA (subG1 peak)}

As a third parameter of late apoptosis, the appearance of a subG1 peak was investigated at different time points by flow cytometry. While neither $\mathrm{CuO} \mathrm{MP}$ nor $\mathrm{CuCl}_{2}$ increased the control value of less than $2 \%, \mathrm{CuO} N P$ provoked a dose-dependent increase up to $6.1 \%$ cells containing subdiploid DNA at $50 \mu \mathrm{g} / \mathrm{mL} \mathrm{CuO} \mathrm{NP}$ after $24 \mathrm{~h}$ (Figure 4B). The appearance of the enlarged subG1 peak was also time-dependent, starting at $8 \mathrm{~h}$, increasing at $16 \mathrm{~h}$ (data not shown) and being most pronounced after $24 \mathrm{~h}$. The positive control staurosporine induced subdiploid DNA in $11.4 \%$ of cells after $24 \mathrm{~h}$.

\section{Direct and indirect genotoxicity}

To determine and compare the genotoxicity of the three copper compounds, four parameters have been included. First, the potency to induce DNA strand breaks has been determined by Alkaline Unwinding. Second, since copper may catalyse Fenton-type reactions, the induction of DNA strand breaks under pro-oxidative conditions, i.e., elevated levels of $\mathrm{H}_{2} \mathrm{O}_{2}$, was investigated. Third, the induction of micronuclei was determined as a measure of chromosomal damage. Finally, the impact on poly(ADPribosyl)ation was explored, since this reaction has been shown previously to be inhibited at comparatively low concentrations of water soluble copper [6], indicative of indirect genotoxicity via inhibition of enzymes involved in maintaining genomic stability.

\section{Induction of DNA strand breaks}

After $24 \mathrm{~h}$ incubation $\mathrm{CuO}$ NP induced DNA strand breaks in HeLa S3 cells in a concentration-dependent manner, starting at the non-cytotoxic concentration of $10 \mu \mathrm{g} / \mathrm{mL}$ and reaching 0.8 DNA strand breaks $/ 10^{6}$ base pairs at $20 \mu \mathrm{g} / \mathrm{mL}$. No significant induction was seen in case of $\mathrm{CuO} \mathrm{MP}$ or with $\mathrm{CuCl}_{2}$ (Figure $5 \mathrm{~A}$ ). However, in the presence of elevated levels of $\mathrm{H}_{2} \mathrm{O}_{2}$ all three copper compounds increased the number of DNA strand breaks. While treatment with $35 \mu \mathrm{M} \mathrm{H} \mathrm{H}_{2} \mathrm{O}_{2}$ for 5 min alone revealed 0.4 DNA strand breaks $/ 10^{6}$ base pairs, this value was increased most pronounced by $\mathrm{CuO}$ NP up to 1.6 DNA strand breaks $/ 10^{6}$ base pairs. Under these prooxidative conditions, also $\mathrm{CuO} \mathrm{MP}$ and $\mathrm{CuCl}_{2}$ caused significant elevations of $\mathrm{H}_{2} \mathrm{O}_{2}$-induced DNA strand breaks (Figure 5B). 


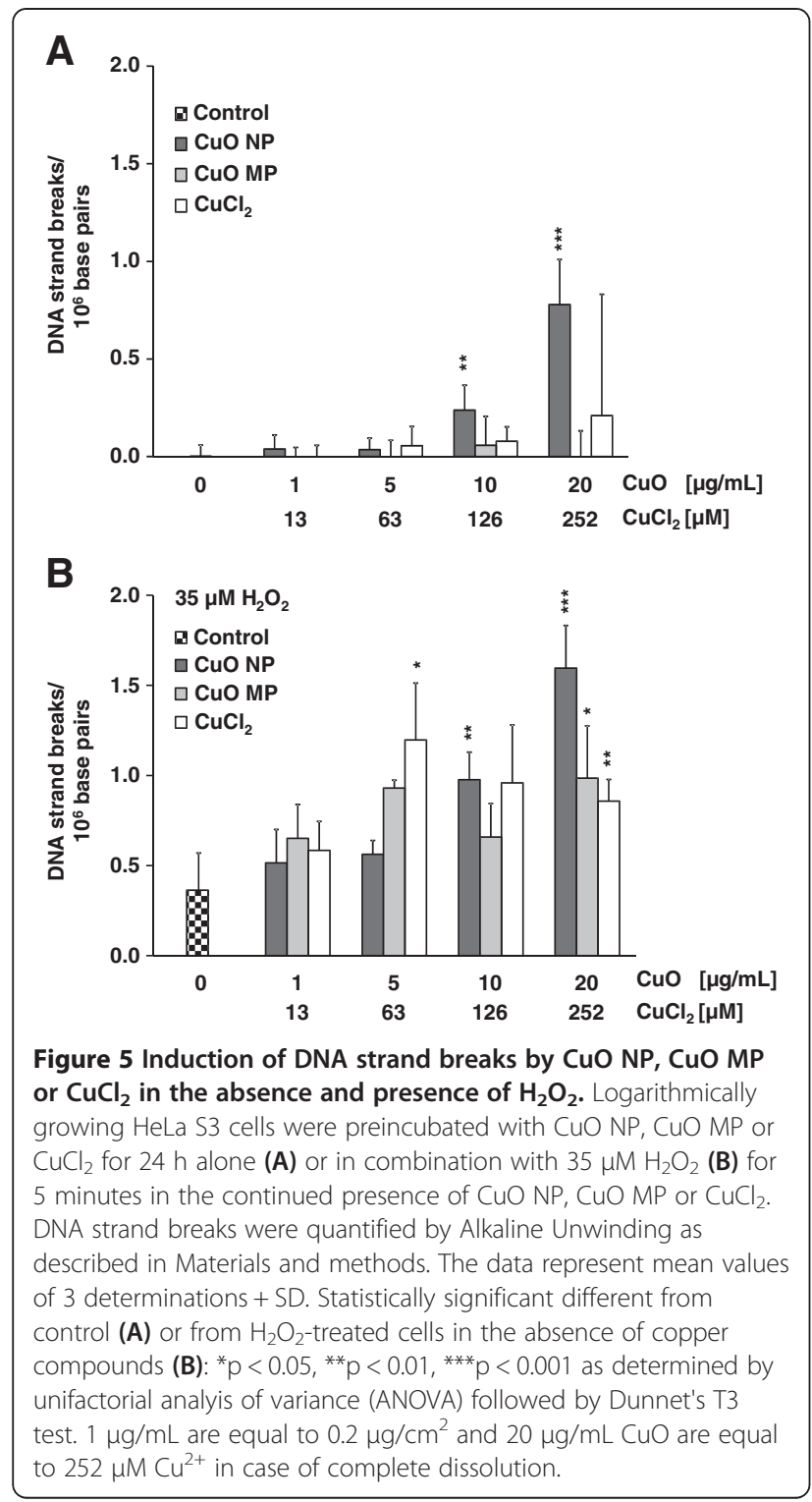

\section{Induction of micronuclei}

The formation of micronuclei $(\mathrm{MN})$ was determined by a flow cytometric approach established by Bryce et al. [26]. The evaluation of micronuclei is based on a twocolour-fluorescence staining of the DNA to discriminate between micronuclei and DNA fragments generated during apoptosis or necrosis. In a first step, the red dye ethidium bromide monoazide (EMA) penetrates necrotic and apoptotic cells due to their damaged cell membrane and binds to nucleic acids. Subsequently, the cells are lysed and their nucleic acids are stained with SYTOX Green. Consequently, the necrotic and apoptotic cells exhibit a double staining and due to different wavelengths of emission it is possible to discriminate between micronuclei (green) and DNA fragments from apoptotic or necrotic cells (red/green). The positive control $10 \mathrm{~J} / \mathrm{m}^{2} \mathrm{UVC}$ induced 105 micronuclei/1000 cells. Even though there was a tendency towards higher frequencies of micronuclei in case of cytotoxic concentrations of $\mathrm{CuO} \mathrm{NP}$, this effect was not significant and would not be informative at these levels of toxicity; neither $\mathrm{CuO} \mathrm{MP}$ nor $\mathrm{CuCl}_{2}$ induced micronuclei at concentrations up to $50 \mu \mathrm{g} / \mathrm{mL}(\mathrm{CuO})$ or $630 \mu \mathrm{M}\left(\mathrm{CuCl}_{2}\right)$ (Figure 6).

\section{Effect on poly(ADP-ribosyl)ation}

To analyse the extent of poly(ADP-ribosyl)ation we determined the formation of poly(ADP-ribose) after activation with $\mathrm{H}_{2} \mathrm{O}_{2}$ immunologically, by applying the highly specific monoclonal antibody $10 \mathrm{H}$ against poly(ADPribose) and a secondary FITC-conjugated antibody. $\mathrm{CuO} \mathrm{NP}$, $\mathrm{CuO} \mathrm{MP}$ as well as $\mathrm{CuCl}_{2}$ decreased the extent of $\mathrm{H}_{2} \mathrm{O}_{2}$ induced poly(ADP-ribosyl)ation concentration-dependent to around $44 \%$ at non-cytotoxic concentrations of $10 \mu \mathrm{g} / \mathrm{mL}$ $\mathrm{CuO}$ or $126 \mu \mathrm{M} \mathrm{CuCl}_{2}$. While no further inhibition was observed in case of $\mathrm{CuO} \mathrm{MP}$ and $\mathrm{CuCl}_{2}$, incubation with $20 \mu \mathrm{g} / \mathrm{mL} \mathrm{CuO} \mathrm{NP}$ inhibited poly(ADP-ribosyl)ation most pronounced to a residual activity of $28 \%$ (Figure 7 ).

\section{Cellular uptake and intracellular bioavailability}

One important aspect which may relate to the observed differences in cyto- and genotoxicity of $\mathrm{CuO}$ NP as opposed to $\mathrm{CuO} \mathrm{MP}$ are potential differences in uptake, intracellular distribution and intracellular deliberation of copper ions, which may in turn provoke copper overload in cells. Since it is difficult to remove all particles from extra- and intracellular membranes to prevent artifacts in copper ion quantification, within the present study an approach was chosen where only copper present in the

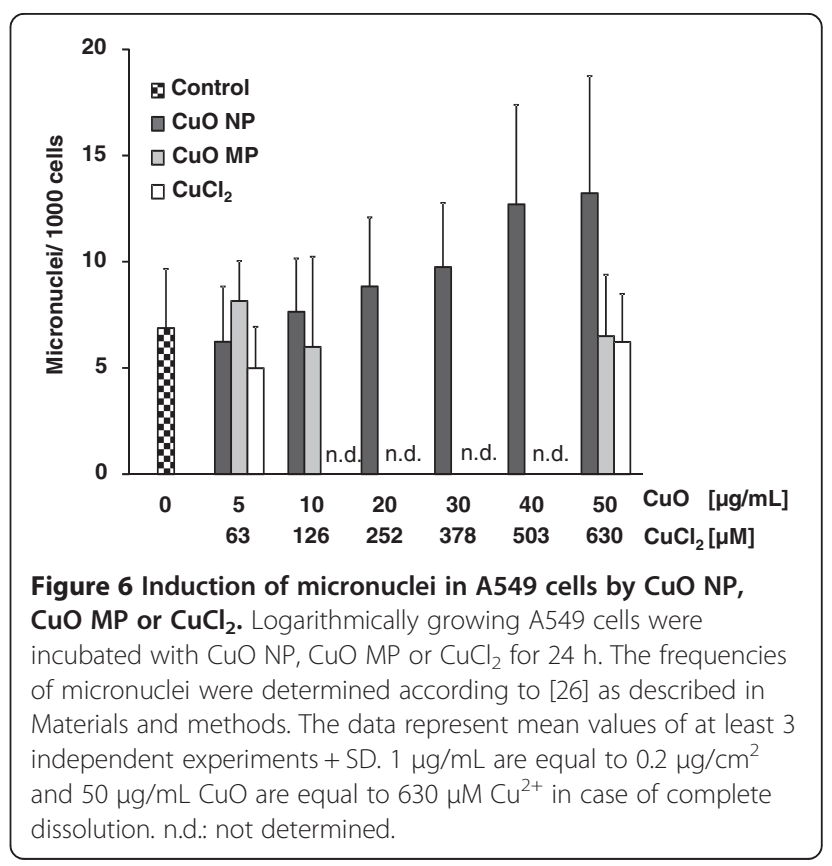




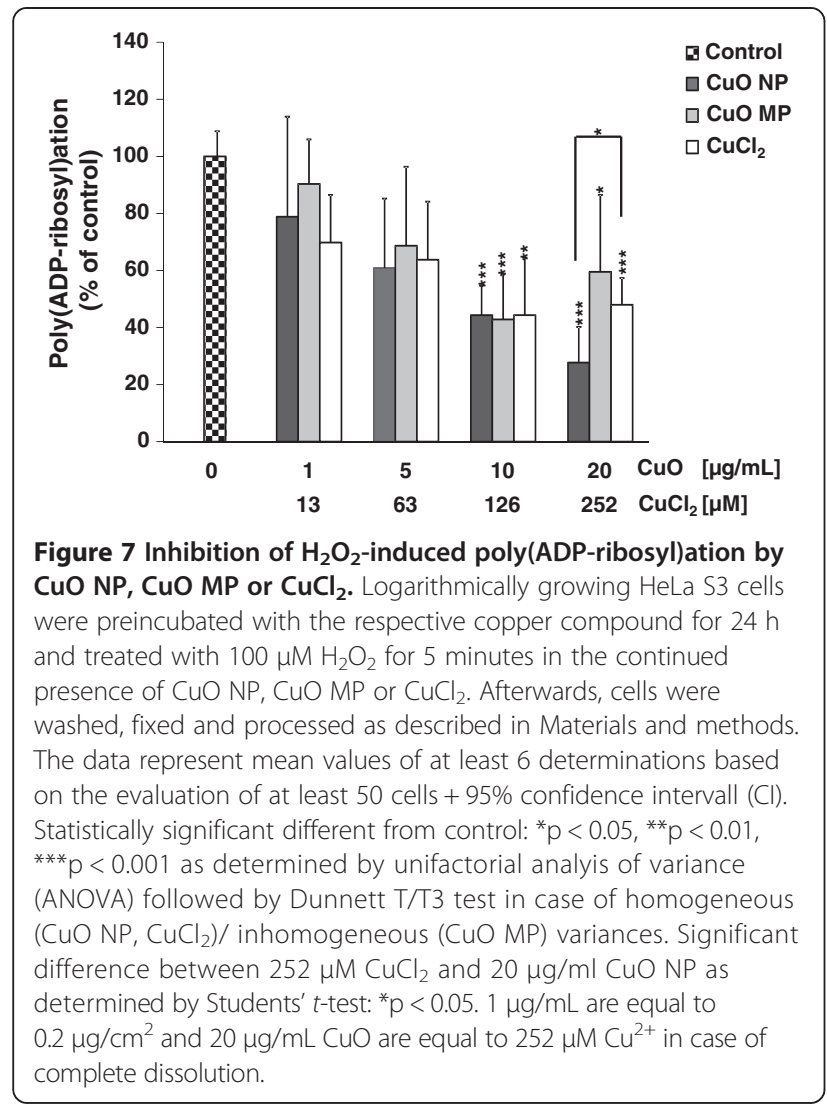

soluble fractions of the cytoplasm and the nucleus were determined. Thus, to quantify the bioavailability and intracellular distribution of ionic copper derived from dissolution of $\mathrm{CuO}$ particles as well as from $\mathrm{CuCl}_{2}$, A549 cells were incubated with the respective copper compound for $24 \mathrm{~h}$. Subsequently, the cells were lysed and the soluble cytoplasmic fraction was isolated, followed by lysis of the nuclei to derive the soluble nuclear fraction. Copper contents were calculated based on cell or nuclei volume as well as on the protein content of the respective fraction. The basal copper level of A549 cells was found to be $15 \mu \mathrm{M}$ in the cytoplasmic and $27 \mu \mathrm{M}$ in the nuclear fraction. Treatment with either $\mathrm{CuO} \mathrm{NP}$ or $\mathrm{CuCl}_{2}$ provoked a concentration-dependent copper accumulation in the cytoplasmic fraction. Thus, the lowest incubation concentration of $5 \mu \mathrm{g} / \mathrm{mL} \mathrm{CuO}$ $\mathrm{NP}$ or $63 \mu \mathrm{M} \mathrm{CuCl}{ }_{2}$ increased the basal cytoplasmic copper level by 22 -fold to around $330 \mu \mathrm{M}$, reaching $630 \mu \mathrm{M}$ at $252 \mu \mathrm{M} \mathrm{CuCl}$ and $680 \mu \mathrm{M}$ at $20 \mu \mathrm{g} / \mathrm{mL}$ $\mathrm{CuO}$ NP. In case of $\mathrm{CuO}$ MP the cytoplasmic copper content was quite variable and lead to very high standard deviations. In the nuclear fraction, highest copper concentrations of more than $1 \mathrm{mM}$ were reached after treatment with 10 or $20 \mu \mathrm{g} / \mathrm{mL} \mathrm{CuO} \mathrm{NP}$, while $\mathrm{CuO}$ MP yielded around $600 \mu \mathrm{M}$ at the same incubation concentrations. Lowest levels were observed after treatment with $\mathrm{CuCl}_{2}$, reaching about $400 \mu \mathrm{M}$, but lacking a clear dose-dependency (Figure 8A,B).

\section{Discussion}

The results presented in this study confirm previous observations with respect to the distinct cytotoxicity of $\mathrm{CuO}$ $\mathrm{NP}$; aim of the present study was to elucidate the underlying mechanism(s). Reasons for the particularly high cytotoxicity of $\mathrm{CuO}$ NP may be a direct interaction of undissolved particles with cellular components including the plasma membrane, perhaps facilitated by the 23 -fold higher surface area of the $\mathrm{CuO} \mathrm{NP}$ when compared to the $\mathrm{CuO} \mathrm{MP}$, or by copper ions deliberated either extracellularly or intracellularly. Even though copper is an essential trace element, elevated intracellular levels may exceed copper homeostasis, giving rise to pro-oxidative reactions. Thus, within this study, three different copper compounds, namely $\mathrm{CuO} \mathrm{NP}, \mathrm{CuO} \mathrm{MP}$ and water soluble $\mathrm{CuCl}_{2}$, were, based on their total copper

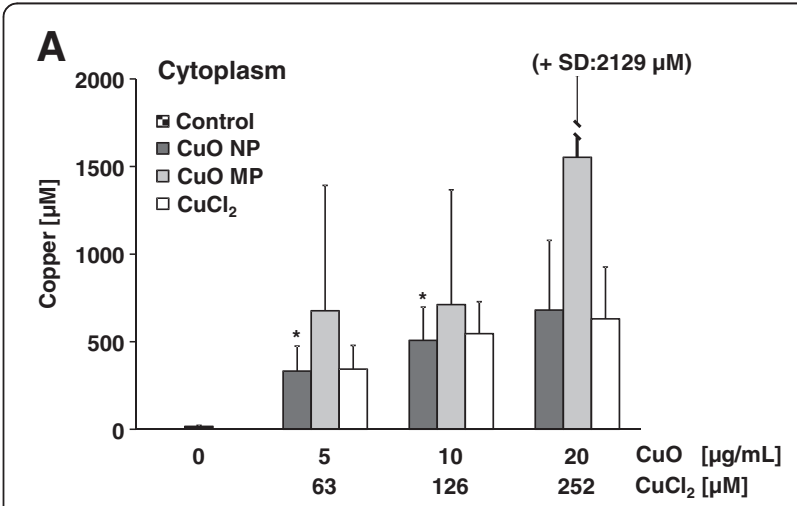

B

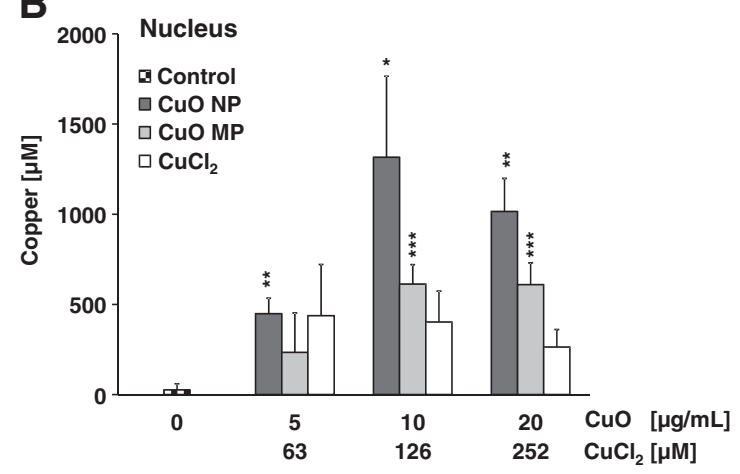

Figure 8 Copper bioavailability and intracellular distribution after incubation with CuO NP, CuO MP or $\mathrm{CuCl}_{2}$ in $\mathrm{A} 549$ cells. Logarithmically growing A549 cells were incubated for $24 \mathrm{~h}$ with $\mathrm{CuO} \mathrm{NP}$, CuO MP or $\mathrm{CuCl}_{2}$. Subsequently, (A) nuclear and (B) cytoplasmic protein fractions were isolated and the copper content was quantified by ICP-MS as described in Materials and methods. The data represent mean values of at least 3 independent experiments + SD. Statistically significant different from control: ${ }^{*} p<0.05,{ }^{* *} p<0.01$ as determined by unifactorial analysis of variance (ANOVA) and Dunnett's T3 test. $1 \mu \mathrm{g} / \mathrm{mL}$ are equal to $0.2 \mu \mathrm{g} / \mathrm{cm}^{2}$ and $20 \mu \mathrm{g} / \mathrm{mL}$ $\mathrm{CuO}$ are equal to $252 \mu \mathrm{M} \mathrm{Cu}^{2+}$ in case of complete dissolution. 
content, systematically compared with respect to cytotoxicity, their dissolution in extra- and intracellular media, the actual intracellular and intranuclear concentrations reached upon treatment of A549 cells as well as oxidative stress-mediated genotoxicity. The data demonstrate that in spite of pronounced differences in cytotoxicity all copper compounds investigated are in principle bioavailable; as for water soluble copper, this leads to highly elevated intracellular copper levels also in case of the particulate compounds. Among the three copper compounds, $\mathrm{CuO} \mathrm{NP}$ revealed higher concentrations in the nucleus. While the differences in intracellular bioavailability are not sufficient to explain the differences in cytotoxicity, especially the copper accumulation in the nucleus appears to correlate with the extent of genotoxicity.

To assess the cytotoxicity, the colony forming ability was investigated as a sensitive parameter of long-term toxicity in A549 and HeLa S3 cells. While no toxicity was observed in case of $\mathrm{CuO} \mathrm{MP}$ in the concentration range applied up to $50 \mu \mathrm{g} / \mathrm{mL}$, pronounced dosedependent toxicity was observed after $24 \mathrm{~h}$ incubation with $\mathrm{CuO} \mathrm{NP}$ or $\mathrm{CuCl}_{2}$ in both cell lines. While $\mathrm{CuO}$ NP exerted similar effects in A549 and HeLa S3 cells, $\mathrm{CuCl}_{2}$ was slightly less toxic in A549 cells. In principle, with respect to $\mathrm{CuO} \mathrm{NP}$ and $\mathrm{CuO} \mathrm{MP}$, the results confirm previous observations on the cytotoxicity of differently sized $\mathrm{CuO}$ in mammalian cells [20,21,27]. Nevertheless, they contradict in part observations by Karlsson et al. [19] where equimolar levels of $\mathrm{CuCl}_{2}$ were eight times less cytotoxic to A549 cells than CuO NP after 18 h incubation. However, these authors applied trypan blue exclusion as a measure of cytotoxicity, which may be less sensitive when compared to colony forming ability applied in the present study. Concerning the mechanism of cell death, pronounced differences were seen between $\mathrm{CuO} \mathrm{NP}$ and $\mathrm{CuCl}_{2}$ : Only $\mathrm{CuO} \mathrm{NP}$ induced significant elevations of the SubG1-peak, indicative of apoptosis, while no effect was seen in case of $\mathrm{CuCl}_{2}$. Furthermore, $\mathrm{CuO} \mathrm{NP}$ caused a slight increase in AIF nuclear translocation, pointing towards mitochondrial membrane damage. These observations agree with previous studies on the translocation of phosphatidylserine by $\mathrm{CuO} \mathrm{NP}$ [16] and the depolarization of the mitochondrial membrane potential by $\mathrm{CuO}$ NP $[17,20]$. Mitochondrial damage may be the consequence of direct interactions with undissolved particles after endocytotic uptake and/or by ROS-derived lipid peroxidation resulting in disturbed membrane integrity and the release of apoptotic enzymes.

To elucidate the impact of released copper ions on the cytotoxicity, the dissolution of $\mathrm{CuO} \mathrm{NP}$ and $\mathrm{CuO} \mathrm{MP}$ in different model fluids was quantified. Decisive parameters both for the dissolution and for agglomeration/ aggregation may be the composition of buffers and cell culture media, the presence of proteins, for example due to the addition of fetal calf serum, as well as the $\mathrm{pH}$. We found a higher solubility in case of $\mathrm{CuO}$ NP when compared to $\mathrm{CuO} \mathrm{MP}$ in bidistilled water and in PBS; however both copper oxides dissolved only sparsely $(<3 \%)$, in agreement with two previous studies [21,28] and the reported hydrophobicity of $\mathrm{CuO} \mathrm{NP}$ [29]. Since the lung is one important target organ for $\mathrm{CuO}$ particle toxicity, also artificial alveolar fluid (AAF) was included; again, the solubility was higher for $\mathrm{CuO} N \mathrm{NP}$ than for $\mathrm{CuO} \mathrm{MP}$, but was altogether very low with values below or around $1 \%$. Thus, CuO NP and CuO MP dissolved only marginally in aqueous liquids at neutral $\mathrm{pH}$. With respect to cell culture experiments we investigated the dissolution of $\mathrm{CuO} \mathrm{NP}$ and $\mathrm{CuO}$ MP in DMEM and DMEM/FCS. Here, the dissolution was much higher for both particle types. In DMEM/FCS, CuO NP dissolved ten times stronger (44\%) than $\mathrm{CuO} \mathrm{MP}(4 \%)$ after $24 \mathrm{~h}$ in good agreement with two former studies [16,30]. For comparison, in DMEM without FCS dissolution was even higher (66\% in case of $\mathrm{CuO} \mathrm{NP}$ and $27 \%$ in case of $\mathrm{CuO} \mathrm{MP}$ ). Concerning DMEM, the accelerated dissolution may be explained by the presence of copper ion complexing amino acids; the addition of fetal calf serum may result in a protein corona around the particles [12,31], which in this case appears to protect both types of particles from dissolution. However, one has also to consider the conditions in different intracellular compartments. Both nano- and microsized particles have been shown to be taken up via endocytosis, involving the formation of endosomes ( $\mathrm{pH}$ 6.2), and their transformation into lysosomes (pH 4.5) [15]. Thus, within this study, the dissolution was followed in the acidic environment of an artificial lysosomal fluid (ALF) for 30 minutes to $7 \mathrm{~d}$. $\mathrm{CuO}$ NP dissolved almost completely after $2 \mathrm{~h}$ in ALF at $\mathrm{pH} 4.5$; nevertheless, it took $7 \mathrm{~d}$ to dissolve $\mathrm{CuO} \mathrm{MP}$. With respect to the former particles, dissolution in ALF was even faster when compared to $3 \mathrm{~d}$ required for dissolution of $\mathrm{CuO} \mathrm{NP}$ in a complexing bis-Tris solution reported in literature [28]. The data demonstrate the relevance of comprehensive model studies related to intra- and extracellular dissolution of particles; an estimation based on the largely insolubility of $\mathrm{CuO}$ particles in bidistilled water or buffer would not allow to detect the pronounced differences between nano- and microscale particles.

With respect to the intracellular bioavailability, two aspects have to be considered, namely the internalization of particles and the increase in water soluble copper ions within the cell. Concerning the uptake of particles, three studies investigated the uptake of $\mathrm{CuO}$ NP into human cells by TEM [16-18]. Thus, Wang et al. observed aggregates of $\mathrm{CuO} \mathrm{NP}$ in lysosomes, mitochondria and the cell nucleus and, by applying an endocytosis inhibitor, 
demonstrated the importance of endocytosis for particle uptake [17]. Within the present study we aimed to elucidate the impact of the three copper compounds on the levels of copper ions in the cytoplasm and the cell nucleus. Since copper particles associated with plasma and intracellular membranes are difficult to remove and would potentially lead to artifacts with respect to ionic copper concentrations, we applied a protocol where successively cytoplasmic and nuclear soluble fractions were isolated [32]. The principle consists in lysis of the plasma membrane and subsequent centrifugation; the supernatant contains the soluble cytoplasmic fraction. Subsequently, the precipitated nuclei are lysed and centrifuged to obtain the soluble nuclear fraction in the supernatant. For all three copper compounds, we observed a pronounced increase in copper concentrations both in the cytoplasm and the nucleus of A549 cells. Concerning $\mathrm{CuO} \mathrm{NP}$ and water soluble copper chloride, the basal copper concentration in the cytoplasm was accelerated up to 45- and 42-fold and about 38- and 15 -fold in the nucleus, respectively. In case of $\mathrm{CuO} \mathrm{MP}$ the standard deviation between experiments was very high, which may be due to the presence of incompletely dissolved particles in the lysosomes; here, small differences in particle numbers would give rise to extended variations in the copper content. In support of this theory, error bars in case of $\mathrm{CuO} \mathrm{NP}$ are much smaller, which could be explained by their much faster dissolution in the lysosomes. With respect to the nuclear fraction, highest concentrations were obtained in case of $\mathrm{CuO} \mathrm{NP}$, reaching $1.3 \mathrm{mM}$ copper. These findings appear to contradict results by Wang et al. [17] as well as by Cronholm et al. [18] who reported about 20-fold (Wang) or 40 fold (Cronholm) higher intracellular concentrations in case of $\mathrm{CuO}$ NP. The pronounced differences may be due to the applied preparation techniques. As indicated above, in the present study the soluble fractions of both cellular compartments were isolated, while Wang and coworkers as well as Cronholm and coworkers used washing and centrifugation procedures before GFAAS measurements of metal content; by this approach, particles may not have been completely removed from the plasma membrane or intracellular membranes. Nevertheless, Wang et al. also found unusual high values for copper in control cells, while basal copper levels of around $20 \mu \mathrm{M}$ observed in the present study are in the range of values reported previously for mouse hepatocytes [33].

One key mechanism of copper toxicity consists in its redox activity, leading to Fenton-type reactions in the presence of $\mathrm{H}_{2} \mathrm{O}_{2}$ and generating highly reactive hydroxyl radicals. Damage to cellular macromolecules including DNA can occur if the storage capability for copper is exceeded, e.g. due to overload conditions, or if oxidative stress induces a sudden release of copper from metallothionein $[1,34]$. In the present study, the induction of DNA strand breaks was investigated as an indicator of oxidative stress. CuO NP induced DNA strand breaks in HeLa S3 cells already at non-cytotoxic concentrations of $10 \mu \mathrm{g} / \mathrm{mL}$, whereas the induction by $\mathrm{CuCl}_{2}$ and $\mathrm{CuO} \mathrm{MP}$ was negligible. With respect to $\mathrm{CuO} \mathrm{NP}$, our results are consistent with former studies where the authors detected elevated levels of DNA damage by $\mathrm{CuO}$ NP using the comet assay $[17,19,21,24]$ and which may in addition to the highly enhanced intracellular copper levels also be due to increased mitochondrial damage $[17,20]$, facilitating Fenton-type reactions. Regarding water soluble $\mathrm{CuCl}_{2}$, our data seem to contradict previous results where water soluble $\mathrm{CuSO}_{4}$ induced DNA strand breaks [6]; nevertheless, this effect was restricted to cytotoxic concentrations $>300 \mu \mathrm{M}$, while the highest concentration included in our study was around $250 \mu \mathrm{M}$ and still in the non-cytotoxic concentration range. Interestingly, all three compounds under investigation caused an increase in the number of $\mathrm{H}_{2} \mathrm{O}_{2}$-induced DNA strand breaks, indicative of an augmentation of pro-oxidative conditions within the cell. With regard to DNA damage on the chromosomal level, only $\mathrm{CuO}$ NP exerted a tendency of increased micronuclei formation. At the highest concentration investigated the number of micronuclei was non-significantly doubled. With respect to $\mathrm{CuO} N P$ our results do not resemble those observed in vivo [22] and also appear to contradict significantly enhanced levels of micronuclei in a neuroblastoma cell line and RAW 264.7 cells $[23,24]$. Nevertheless, the latter may be explained by different experimental approaches. Thus, Perrault and coworkers [23] as well as Di Bucchianico and coworkers [24] collected cells by cytochalasin B, and thereby detected micronuclei which arise either by clastogenic or aneugenic effects. In contrast, the flow cytometric approach conducted within the present study is restricted to the detection of clastogenic effects.

One further aspect investigated within the present study is the impact of copper-based particles on poly (ADP-ribosyl)ation. Poly(ADP-ribosyl)ation is one of the earliest events following the induction of DNA strand breaks and is catalysed by members of the poly(ADPribose)polymerase (PARP) super family, mostly by PARP1 [35]. Poly(ADP-ribosyl)ation is a posttranslational modification of proteins, where multiple ADP-ribose moieties derived from $\mathrm{NAD}^{+}$are covalently attached to acceptor proteins like histones, transcription factors or DNA repair proteins. This reaction is thought to mediate DNA damage signalling and plays an important role in maintaining genomic stability, best understood for base excision repair (BER) and the initial steps of single strand break repair (SSBR) [36]. PARP-1 contains three zincbinding domains, two of which are required for DNA binding [37], thereby protecting DNA strand breaks from 
conversion into more disadvantageous lesions, e.g. via attack of nucleases and/or recombination [38,39]. Previous studies in our laboratory identified PARP-1 as well as poly(ADP-ribosyl)ation as sensitive target of water soluble copper sulfate [6]; thus, within the present study this endpoint was included to assess the impact of particulate copper compounds. The results demonstrate a dosedependent inhibition by all three copper compounds, starting at non-cytotoxic concentrations; nevertheless, the strongest inhibition to about $28 \%$ residual activity was seen in case of $\mathrm{CuO}$ NP. In principle, different mechanisms could apply for the observed inhibition of poly (ADP-ribosyl)ation. As PARP-1 is activated upon the recognition and binding to DNA strand breaks, an inhibition could be due to a diminished induction of DNA strand breaks in combination with $\mathrm{H}_{2} \mathrm{O}_{2}$. Nevertheless, this can be excluded since all three copper compounds even increased the frequency of $\mathrm{H}_{2} \mathrm{O}_{2}$-induced DNA strand breaks under the same incubation conditions. Another reason could be a depletion of $\mathrm{NAD}^{+}$, the substrate of PARP-1. Nevertheless, since the inhibition was observed at non-cytotoxic concentrations where neither cell growth nor cell division was impaired, this reason seems unlikely as well. Also, $\mathrm{CuO} \mathrm{MP}$ did not affect the cell growth of HeLa S3 cells at any concentration and yet was still inhibitory towards poly(ADP-ribosyl)ation. The most likely explanation is a direct inhibition of PARP-1 by copper ions under overload conditions. Thus, in a previous study we observed a diminished activity of isolated PARP-1 by copper sulfate [6]. Copper ions are redox-active and may react with redox-sensitive amino acids. Potential targets may be thiol groups in cysteines, for example those involved in zinc complexation within the zinc binding structures of PARP-1, leading to zinc deliberation and unfolding of the respective domains required for the recognition of DNA strand breaks and the catalytic activity of PARP-1 $[37,40]$. Also, copper ions may bind directly to thiols, thus leading to structural alterations. The more pronounced inhibition by $\mathrm{CuO} \mathrm{NP}$ as compared to $\mathrm{CuO} \mathrm{MP}$ and $\mathrm{CuCl}_{2}$ may be explained by elevated copper levels in the nucleus observed in case of $\mathrm{CuO}$ NP.

\section{Conclusion}

In summary, the results presented in this study support the high cytotoxicity of $\mathrm{CuO} \mathrm{NP}$ as described previously. By systematic comparison of $\mathrm{CuO} \mathrm{NP}, \mathrm{CuO} \mathrm{MP}$ and water soluble copper chloride, the impact of particle size, extracellular solubility and intracellular dissolution and thus bioavailability of copper ions on cytotoxicity as well as direct and indirect genotoxicity was investigated. With regard to cytotoxicity, the total copper content and the intracellular copper levels appear to be of minor importance, since $\mathrm{CuO} \mathrm{MP}$ are not cytotoxic and yet increase nuclear copper levels to a higher extent than
$\mathrm{CuCl}_{2}$, which is clearly toxic based on the same copper content. $\mathrm{CuO}$ NP were most cytotoxic and the only compound inducing apoptosis. Thus, the high cytotoxicity is most likely related to particle characteristics like the high surface area (about 23-fold higher when compared to $\mathrm{CuO} \mathrm{MP}$ ), which may facilitate redox reactions either intra- or extracellularly, leading to cell death. Additionally, it has to be taken into account that a considerable fraction of the nanoparticles but not of the microparticles has been dissolved already in the incubation medium; therefore copper ions either present or released extracellularly may contribute to the cytotoxicity as well. Concerning genotoxicity, especially the copper levels in the nucleus appear to be relevant. Here, highest levels were observed in case of $\mathrm{CuO} \mathrm{NP}$, and this was also the only compound which generated DNA strand breaks in the absence of (additional) $\mathrm{H}_{2} \mathrm{O}_{2}$ and exerted the most pronounced inhibition of poly(ADP-ribosyl)ation. Taken together, different features of $\mathrm{CuO} \mathrm{NP}$ appear to affect cyto- and genotoxicity, and especially the intra-nuclear bioavailability of copper ions exceeding cellular copper homeostasis may impair genomic stability.

\section{Materials and methods}

\section{Particles and metal compounds}

CuO NP (\#544868, Lot \#MKAA0633), CuO MP (\#208841, Lot \# MKAA1788) and $\mathrm{CuCl}_{2}$ (\#307483) were purchased from Sigma-Aldrich Chemie GmbH (Steinheim, Germany). Storage occurred in containers of amber glass ( $\mathrm{CuO} N \mathrm{NP})$ or High Density Polyethylene (HD-PE) (CuO MP) in dry places at room temperature (RT). The particulate materials were characterized using DLS with respect to size, scanning electron microscopy (SEM) for size and morphology, BET for surface area, ZP for surface charge, ICP-MS, EDX and oxygen analysis for purity and composition as well as X-ray Diffraction (XRD) for crystallinity. The particles were also investigated with respect to their impact on $\mathrm{pH}$ in relevant media. Finally, an endotoxin contamination was excluded.

\section{Metrics}

The particle dose is stated in mass concentration $[\mu \mathrm{g} / \mathrm{mL}]$. For the purpose of comparison the conversion into other common metrics as area-related mass $\left[\mu \mathrm{g} / \mathrm{cm}^{2}\right]$, surface area concentration $\left[\mathrm{cm}^{2} / \mathrm{mL}\right]$ and molar concentration $[\mu \mathrm{M}]$ is given in Table 1 .

\section{Preparation of endotoxin-free materials}

Snap-on lid glasses equipped with adequate teflon jacketed stirring bars were utilized for preparing the particle incubation suspensions. Prior to use, the glasses and stirring bars were rinsed with sterile filtered ultrapure water $\left(\mathrm{H}_{2} \mathrm{O}\right)(18 \mathrm{~m} \Omega)$ to remove inorganic contaminations, followed by treatment with $70 \%$ ethanol prepared 
Table 1 Metrics

\begin{tabular}{lllll}
\hline $\begin{array}{l}\mathrm{CuO} \\
{[\mu \mathrm{g} / \mathrm{mL}]}\end{array}$ & $\begin{array}{l}\text { CuO } \\
{\left[\mu \mathrm{g} / \mathrm{cm}^{2}\right]}\end{array}$ & $\begin{array}{l}\text { Copper } \\
{[\mu \mathrm{M}]}\end{array}$ & $\begin{array}{l}\text { CuO NP } \\
{\left[\mathrm{cm}^{2} / \mathrm{mL}\right]^{*}}\end{array}$ & $\begin{array}{l}\text { CuO MP } \\
{\left[\mathrm{cm}^{2} / \mathrm{mL}\right]^{*}}\end{array}$ \\
\hline 1 & 0.2 & 13 & 0.1723 & 0.0074 \\
5 & 1 & 63 & 0.8612 & 0.0369 \\
10 & 2 & 126 & 1.723 & 0.0738 \\
20 & 4 & 252 & 3.446 & 0.1476 \\
30 & 6 & 377 & 5.169 & 0.2214 \\
40 & 8 & 503 & 6.892 & 0.2952 \\
50 & 10 & 630 & 8.615 & 0.3690 \\
\hline
\end{tabular}

Conversion of the applied doses from $\mu \mathrm{g}$ particles $/ \mathrm{mL}$ suspension media $(\mu \mathrm{g} /$ $\mathrm{mL}$ ) into $\mu \mathrm{g}$ particles $/ \mathrm{cm}^{2}$ growth area of a cell culture dish $\left(\mu \mathrm{g} / \mathrm{cm}^{2}\right)$ into $\mu \mathrm{mol}$ copper/L suspension media $(\mu \mathrm{M})$ and $\mathrm{cm}^{2}$ particle surface/mL suspension media $\left(\mathrm{cm}^{2} / \mathrm{mL}\right)$.

*Calculated from the specific surface area measured by BET analysis according to [41].

with sterile filtered $\mathrm{H}_{2} \mathrm{O}$. Endotoxin contamination was excluded by dry sterilization for either $0.5 \mathrm{~h}$ at $250^{\circ} \mathrm{C}$ or $5 \mathrm{~h}$ at $220^{\circ} \mathrm{C}$. The lids were cleaned as stated above and stored in $70 \%$ ethanol; prior to use they were dried in a sterile laminar airflow.

\section{Particle incubation suspensions}

For all experiments incubation suspensions of particles were prepared following a standard operating procedure (SOP) published by the German Nano Care consortium [42]. Particles, received as dry powder, were aliquoted by weighing (scale: BP 61 S, Sartorius, Göttingen, Germany) into colorless, endotoxin-free $1.5 \mathrm{~mL}$ polystyrene reaction tubes (\#72.690.001 Sarstedt, Nümbrecht, Germany). Stock solutions of $0.5-20 \mathrm{mg} / \mathrm{mL} \mathrm{CuO}$ were prepared by transferring an aliquot completely into an endotoxin-free snap-on lid glass containing a stirring bar and replenishing with bidistilled water or medium with or without serum depending on the requirements of the respective experiments to the designated concentration. Each particulate compound and the control media were prepared by applying separate sets of stirring bars. Stock solutions were stirred on a multiphase stirrer (Variomag ${ }^{\circ}$ Poly, Carl Roth $\mathrm{GmbH}$, Karlsruhe, Germany) for $1 \mathrm{~h}$ and $900 \mathrm{rpm}$ at RT. Dilutions in the range of $1-50 \mu \mathrm{g} / \mathrm{mL}$ (cell culture experiments), $100-500 \mu \mathrm{g} / \mathrm{mL}$ (endotoxin tests) and $50-$ $6000 \mu \mathrm{g} / \mathrm{mL}$ (DLS/ZP) were prepared by adding aliquots of the stirring stock solution into snap-on lid glasses filled with adequate volumes of fresh medium. Stirring occurred for $24 \mathrm{~h}$ at $900 \mathrm{rpm}$ and room temperature prior to use. $\mathrm{CuCl}_{2}$ was dissolved in bidestilled $\mathrm{H}_{2} \mathrm{O}(0.4 \mathrm{M})$ and sterile filtered $(0.22 \mu \mathrm{m}$, cellulose acetate). Adequate dilutions were prepared directly before incubation. $\mathrm{CuCl}_{2}$ incubation solutions were prepared as stated above by stirring adequate stock solutions and dilutions at $900 \mathrm{rpm}$ before application.

\section{Cell culture reagents}

DMEM, trypsin and penicillin-streptomycin solutions are products of Sigma-Aldrich. FCS (\#10270, Lot \#41Q7361K) is a product of Invitrogen $\mathrm{GmbH}$ (Darmstadt, Germany). Leupeptine, phenylmethanesulfonyl-fluoride (PMSF), all salts, acids and bases, snap-on lid glasses and stirring bars were obtained from Carl Roth GmbH. Biochrom AG (Berlin, Germany) delivered cell culture dishes and flasks.

\section{Cell lines and cell culture}

The adherent human cancer cell lines A549 (human lung adenocarcinoma cell line) and HeLa S3 (human cervix carcinoma cell line), both derived from ATCC, were maintained and grown as monolayer in DMEM supplemented with $10 \%$ FCS, containing 100 Units $/ \mathrm{mL}$ penicillin and $100 \mu \mathrm{g} / \mathrm{mL}$ streptomycin (DMEM/FCS). Incubation took place in an atmosphere of $5 \% \mathrm{CO}_{2}$ in air at $37^{\circ} \mathrm{C}$ and $100 \%$ humidity (HeraSafe, Thermo Scientific, Langenselbold, Germany). For all experiments cells were seeded at a density of 16,600 cells $/ \mathrm{cm}^{2}$. After one day the supernatant from the logarithmically growing cells was removed and replaced by the particle incubation suspensions $\left(0.2 \mathrm{~mL} / \mathrm{cm}^{2}\right)$ as indicated for the respective experiments.

\section{DLS and ZP}

To determine the hydrodynamic particle size distribution by DLS and the ZP at $20^{\circ} \mathrm{C}$, a Malvern Zetasizer Nano ZS (Malvern, Herrenberg, Germany), equipped with a $532 \mathrm{nM}$ laser, was applied. $1.5 \mathrm{~mL}$ of the respective particle suspension was transferred into a clean square polystyrene cuvette (\#67-754, Sarstedt). In two independent experiments, concentrations were optimized to the devices' performance needs and ten replicates of at least two dilutions per particle were quantified. Measurement conditions such as distance from cuvette wall, number of runs and measurement duration were optimized for each particle. The implemented Zetasizer Nano ZS Dispersion Technology Software (DTS) Version 6.20 evaluated the data as intensity (iPSD), volume (vPSD) and number distribution (nPSD) in combination with parameters like the polydispersity index (PdI) ranging from $0-1$. Thus, 0 reflects a monodisperse and 1 a polydisperse sample. A prerequisite to obtain the best possible result in terms of iPSD, vPSD and nPSD, is the knowledge of the physical characteristics of medium and particles. In the context of this work the refractive index $(n)$, the viscosity $(\eta)$, the dielectric constant $(\varepsilon)$ and the density $(\rho)$ of the cell culture media were obtained as described below for DMEM and DMEM/FCS. DMEM: $\mathrm{n}=1.33, \eta[\mathrm{mPas}]=1.09, \rho\left[\mathrm{g} / \mathrm{cm}^{3}\right]=1.00, \varepsilon=77.9548$; DMEM/FCS: $\mathrm{n}=1.33, \eta[\mathrm{mPas}]=1.14, \rho\left[\mathrm{g} / \mathrm{cm}^{3}\right]=1.00$, $\varepsilon=77.5896$; the refractive index of $\mathrm{CuO}$ is 2.58 [43]. 
Absorption of the $\mathrm{CuO}$ particles was approximated with 0.9 as proposed by Malvern for black particles.

ZP measurements were performed in the folded capillary cell DTS1061C (Malvern Instruments Ltd, Worcestershire, UK), rinsed with $\mathrm{H}_{2} \mathrm{O}$ and ethanol before adding the particle suspensions. For calculation of the ZP from the initially acquired electrophoretic mobility, the Smoluchowski approximation for polar solvents was used. In two independent experiments 3 replicates of at least two dilutions were analysed.

\section{Viscosity}

Using the rheometer Physica MCR 301 (Anton Paar, Graz, Austria) the viscosity was determined at $20^{\circ} \mathrm{C}$. The measurement program contained the following steps: 33 measurements of $5 \mathrm{~s}$ each at $\gamma=0.1 \ldots 1001 / \mathrm{s}, 10$ measurements of $5 \mathrm{~s}$ each at $\gamma=100 \mathrm{1} / \mathrm{s}$ and 33 measurements of $5 \mathrm{~s}$ each at $\gamma=100 \ldots 0.11 / \mathrm{s}$. Calculation of viscosity was conducted with the software RHEOPLUS/32 Multi3 V 3.4 applying the evaluation method Newton I.

\section{Density}

Density was evaluated using a pycnometric procedure, containing the following steps: equilibrating the empty or filled pycnometer to $20^{\circ} \mathrm{C}$ for $30 \mathrm{~min}$, drying and weighing (scale: VWR 1502, Sartorius, Göttingen, Germany). After repeating the procedure with $\mathrm{H}_{2} \mathrm{O}$ and DMEM subsequent calculation resulted in the relative density in $\mathrm{g} / \mathrm{cm}^{3}$.

\section{Refractive index}

The refractive indices of DMEM and DMEM/FCS were determined at $20^{\circ} \mathrm{C}$ using a standard refractometer (Carl Zeiss AG, Oberkochen, Germany).

\section{Dielectric constant}

The dielectric constants of DMEM and DMEM/FCS were determined using the 85070E Dielectric Probe Kit (Agilent Technologies, Inc., Santa Clara, CA, USA). Based on the molecular structure of the materials, the dielectric properties can be determined by a probe transmitting a signal in the range of radio frequency to microwave energy (200 MHz to $50 \mathrm{GHz}$ ) into the material under investigation. A network analyser calculates and displays the complex permittivity including the dielectric constant. Analysis was carried out after calibrating the device against a short circuit, air and $\mathrm{H}_{2} \mathrm{O}$ followed by immersion of the probe into the sample. The dielectric constant was given as a dimensionless number.

\section{Oxygen content}

Oxygen content of the particles was determined using the N/O analyser TC 600 (LECO Instrumente $\mathrm{GmbH}$, Mönchengladbach, Germany).

\section{TEM}

Crystallinity was investigated by X-ray diffraction using a TECNAI G 20 S-TWIN (FEI, Hillboro, OR, USA) at an accelerating voltage of $200 \mathrm{kV}$. Briefly, an aliquot of the particle suspension in $\mathrm{H}_{2} \mathrm{O}$ was placed onto a carbon coated copper grid, dried and subsequently measured. Images were acquired and evaluated with DigitalMicrograph ${ }^{\text {Tw }}$ Software (Gatan, Inc., Pleasanton, CA, USA).

\section{SEM}

Particle size, morphology and chemical composition of the powdered samples were investigated using a LEO 1530 Gemini (Carl Zeiss AG) in combination with EDX at an acceleration voltage of $10 \mathrm{kV}$. Before measurement, the particulate samples were suspended in $\mathrm{H}_{2} \mathrm{O}$, applied onto a silicon specimen holder, dried and sputtered with platinum to increase conductivity.

\section{Specific surface area (BET)}

Prior to measurements the powdered samples were dried for $6 \mathrm{~d}$ at $40^{\circ} \mathrm{C}$ in a vacuum drier (Binder $\mathrm{GmbH}$, Tuttlingen, Germany). Analysis according to the BET [44] theory was conducted in a Gemini 2360 (Micromeritics $\mathrm{GmbH}$, Aachen, Germany). Multipoint BET evaluation resulted in the specific surface area in $\mathrm{m}^{2} / \mathrm{g}$.

\section{pH measurements}

Particle suspensions were prepared as described above in $\mathrm{H}_{2} \mathrm{O}$ and DMEM/FCS. pH value was determined using the $\mathrm{pH} 330 \mathrm{pH}$-meter from WTW GmbH (Weilheim, Germany) equipped with a SenTix electrode.

\section{Endotoxin content}

Particle suspensions with concentrations of $500 \mu \mathrm{g} / \mathrm{mL}$ were prepared in endotoxin-free water. The amount of endotoxin was measured by applying the ToxinSensorTM Endotoxin Detection System Kit (Genscript, Piscataway, USA) according to the manufacturers' instructions.

\section{Solubility in model fluids}

To access the copper ion release, $\mathrm{CuO} \mathrm{NP}$ and $\mathrm{CuO} \mathrm{MP}$ were immersed in $\mathrm{H}_{2} \mathrm{O}, \mathrm{DMEM}, \mathrm{DMEM} / \mathrm{FCS}, \mathrm{PBS}$, AAF or ALF $[45,46]$. Stock suspensions in the respective media were prepared as described above. In case of DMEM and DMEM/FCS the stock suspensions were diluted to a final concentration of $50 \mu \mathrm{g} / \mathrm{mL}$. Thereafter $10 \mathrm{~mL}$ were transferred into cell culture dishes and incubated for $2,4,8,16$ or $24 \mathrm{~h}$ at $37^{\circ} \mathrm{C}$ and $5 \% \mathrm{CO}_{2}$. Subsequently, the suspensions were transferred into centrifuge tubes and centrifuged at $3000 \times \mathrm{g}$ followed by repeated centrifugation of the collected supernatants at $16000 \times \mathrm{g}$. $1 \mathrm{~mL}$ of the resulting supernatant was concentrated by stepwise heating to $95^{\circ} \mathrm{C}$ to remove the water, decomposed by treatment with $1: 1 \mathrm{HNO}_{3}(69 \%) / \mathrm{H}_{2} \mathrm{O}_{2}(31 \%)$ 
(v/v) (quality: suprapure), followed again by stepwise heating to $95^{\circ} \mathrm{C}$. The crystalline residue was solubilized in $1 \mathrm{~mL}$ of $\mathrm{H}_{2} \mathrm{O}$ and analysed for copper content by GFAAS (Pinaccle 900 T, Perkin Elmer, Rodgau, Germany). Potential adsorptive losses by this procedure were excluded by recovery experiments, yielding 103\% copper in case of DMEM/FCS. Successful separation of particles from the liquid was verified by DLS (data not shown).

Solubility of $\mathrm{CuO} \mathrm{NP}$ and $\mathrm{CuO} \mathrm{MP}$ in $\mathrm{H}_{2} \mathrm{O}$, PBS, AAF and ALF was investigated using a modified procedure established for the long-term incubation of up to $7 \mathrm{~d}$. Particle stock suspensions in $\mathrm{H}_{2} \mathrm{O}$, AAF and ALF were prepared as stated above, the respective dilutions $(50 \mu \mathrm{g} / \mathrm{mL})$ were prepared in $50 \mathrm{~mL}$ centrifuge tubes and agitated for 1,4 or $7 \mathrm{~d}$ at $37^{\circ} \mathrm{C}$ using an incubation shaker (MKR 13, HLC-BioTech, Bovenden, Germany) at $100 \mathrm{rpm}$. Centrifugation and oxidative decomposition were carried out as stated above.

\section{Colony forming ability}

Determination of colony forming ability provided details on acute toxicity in terms of cell number and long term toxicity. Logarithmically growing A549 or HeLa cells were incubated for the indicated times, trypsinized and collected in DMEM/FCS. After cell counting (Coulter Z2, Beckmann Coulter GmbH, Krefeld, Germany) triplicates of 300 cells per dish were seeded into fresh medium. After $7 \mathrm{~d}$ colonies were fixed, stained with Giemsa solution and counted.

\section{Subdiploid DNA}

To measure the induction of apoptosis by means of the subG1 peak, cells were seeded, incubated with $\mathrm{CuO}$ NP, $\mathrm{CuO} \mathrm{MP}, \mathrm{CuCl}_{2}$ or as a positive control with $400 \mathrm{nM}$ staurosporine for $4,8,16$ or $24 \mathrm{~h}$. Then the cells were trypsinized, collected in ice-cold PBS/5\% FCS, combined with the supernatant and centrifuged $(1500 \mathrm{rpm}(448 \times \mathrm{g})$, $5 \mathrm{~min}, 4^{\circ} \mathrm{C}$ ). The pellet was resuspended in $1 \mathrm{~mL}$ cold PBS before $3 \mathrm{~mL}$ ice-cold ethanol were added under vortexing, followed by fixation overnight at $-20^{\circ} \mathrm{C}$. For flow cytometric analysis, the samples were centrifuged $(1500 \mathrm{rpm}$, $(448 \times \mathrm{g}), 5 \mathrm{~min}, \mathrm{RT})$, the pellet was resuspended in $1 \mathrm{~mL}$ DAPI dye solution (CyStainDNA, Partec) and incubated for $2 \mathrm{~h}$ at $4^{\circ} \mathrm{C}$ and $2 \mathrm{~h}$ at RT in the dark. $10 \times 10^{5}$ cells per sample were analysed for the occurrence of a SubG1 peak using the software FloMax ${ }^{\oplus}$ (Partec).

\section{Activity of the effector caspases $3 / 7$}

The activity of the effector caspases 3 and 7 was measured using the Caspase-Glo ${ }^{\circ}$ 3/7 Assay Kit (Promega Corporation, Madison, WI, USA). $5.5 \times 10^{3}$ A549 cells were seeded into each well of a white flat-bottomed 96 well plate (Brand, Germany) and allowed to attach for $24 \mathrm{~h}$ before incubation with $\mathrm{CuO} \mathrm{NP}, \mathrm{CuO} \mathrm{MP,} \mathrm{CuCl}_{2}$ or
$400 \mathrm{nM}$ staurosporine as a positive control took place for another $24 \mathrm{~h}$. Subsequently, the assay was conducted according to the instructions given by the manufacturer.

\section{AIF}

Analysis of the AIF release and its translocation from the mitochondria to the cell nucleus was investigated by an immunofluorescent approach using a specific antibody against AIF in combination with a fluorescencecoupled secondary antibody. $12 \mathrm{~mm}$ coverslips were positioned into $40 \mathrm{~mm}$ cell culture dishes before $1.53 \times 10^{5}$ A549 cells were seeded, allowed to attach for $24 \mathrm{~h}$ and incubated with $\mathrm{CuO} \mathrm{NP}, \mathrm{CuO} \mathrm{MP}, \mathrm{CuCl}_{2}$ or $400 \mathrm{nM}$ staurosporine as a positive control, for 4, 8, 16 or $24 \mathrm{~h}$. Subsequently, the culture dishes were positioned on ice, the incubation medium was removed, cover slips were washed three times with $\mathrm{PBS}\left(4^{\circ} \mathrm{C}\right)$ and fixed for $45 \mathrm{mi}$ nutes in ice-cold $3.7 \%$ formaldehyde solution. Thereafter threefold washing with ice-cold PBS was followed by the addition of $0.25 \%$ Triton X-100 in PBS for 25 minutes and a further washing step. Unbound protein binding sites were blocked in PBS/5\% FCS for 5 minutes at RT. The rabbit-polyclonal IgG antibody against AIF (Santa Cruz, Heidelberg, Germany) diluted in blocking buffer (dilution 1:50) was applied to the coverslips and incubated in a humid chamber $\left(30 \mathrm{~min}, 37^{\circ} \mathrm{C}\right)$. Threefold washing in PBS and treatment for 10 minutes in blocking buffer at RT was followed by application of the secondary antibody (Goat-anti rabbit $\mathrm{Cy} 3$ ) in blocking buffer (dilution $1: 300,30 \mathrm{~min}, 37^{\circ} \mathrm{C}$ ). Residuals were removed by threefold washing with PBS and coverslips were prepared on microscope slides by using VECTASHIELD Mounting Medium with DAPI (Biozol, Eching, Germany). The red fluorescence of AIF in the nucleus as well as the nuclei size were analysed and quantified using the Axio Imager.M1 (Zeiss, Oberkochen, Germany) and the software AxioVision version 4.8.

\section{Induction of DNA strand breaks}

DNA strand breaks were quantified by Alkaline Unwinding as described previously [47]. Briefly, $1.53 \times 10^{5} \mathrm{HeLa}$ S3 cells were seeded in cell culture dishes (inner $\varnothing$ $34 \mathrm{~mm}$ ) and allowed to attach for $24 \mathrm{~h}$. Subsequently, cells were incubated for $24 \mathrm{~h}$ with the respective substances alone as well as in combination with $35 \mu \mathrm{M}$ $\mathrm{H}_{2} \mathrm{O}_{2}$ for 5 min. Afterwards, the medium was removed, cells were washed with ice-cold PBS, an alkaline solution (0.03 M NaOH, $0.02 \mathrm{M} \mathrm{Na}_{2} \mathrm{HPO}_{4}, 0.9 \mathrm{M} \mathrm{NaCl}$ ) was added and the DNA was allowed to unwind for 30 minutes in the dark. After neutralization and sonication, singleand double-stranded DNA were separated by performing hydroxyapatite chromatography at $60^{\circ} \mathrm{C}$. Single-stranded DNA was eluted by $0.15 \mathrm{M}$ and double-stranded DNA by $0.35 \mathrm{M}$ potassium phosphate buffer. The addition of 
Hoechst 33258 at a final concentration of $7.5 \times 10^{-7} \mathrm{M}$ to each $\mathrm{mL}$ of sample and measurement of the fluorescence (excitation wave length $360 \mathrm{~nm}$, emission wave length 455 nm) (Infinite M200 Pro, Tecan, Männedorf, Switzerland) was followed by quantification of DNA strand breaks as described previously [47].

\section{Flow cytometric scoring of micronuclei}

Micronuclei were quantified via flow cytometry as described by Bryce et al. [26]. 31,000 A549 cells in $0.4 \mathrm{~mL}$ DMEM/FCS were seeded into each cavity of a 24 well plate and allowed to attach for $24 \mathrm{~h}$. Subsequently, cells were incubated for $24 \mathrm{~h}$ with $\mathrm{CuO} \mathrm{NP}, \mathrm{CuO} \mathrm{MP}$ or $\mathrm{CuCl}_{2}$. As a positive control, cells were irradiated with $10 \mathrm{~J} / \mathrm{m}^{2} \mathrm{UVC}(254 \mathrm{~nm})$. After completion of postincubation $(24 \mathrm{~h})$ the plate was precooled on ice for 20 minutes before the medium was removed. Under exclusion of direct light, $300 \mu \mathrm{L}$ ice-cold dye solution $(8.5 \mu \mathrm{g} / \mathrm{mL}$ EMA (Invitrogen, Darmstadt, Germany)) in PBS/2\% FCS) were added into each well. Irradiation of the plate without lid (30 min, on ice) with the light of a cold light halogen lamp (distance $15 \mathrm{~cm}$ ) was followed by a washing step with $1 \mathrm{~mL}$ of cold buffer (PBS/2\% FCS). Afterwards, $500 \mu \mathrm{L}$ lysis solution A $(58.4 \mathrm{mg} / 100 \mathrm{~mL} \mathrm{NaCl}$ $(10 \mathrm{M}), \quad 0.114 \mathrm{~g} / 100 \mathrm{~mL}$ sodium citrate dihydrate (0.442 mM), $30 \mu \mathrm{L} / 100 \mathrm{~mL}$ IGEPAL, $0.5 \mathrm{mg} / \mathrm{mL}$ RNAse (Roche, Grenzach-Wyhlen, Germany), 0.4 $\mu \mathrm{M}$ SYTOX Green (Invitrogen)) was added and incubated in the dark $\left(1 \mathrm{~h}, 37^{\circ} \mathrm{C}\right)$. Hereafter, $500 \mu \mathrm{L}$ freshly prepared lysis solution B (8.56 g/100 mL sucrose $(25 \mathrm{mM}), 1.5 \mathrm{~g} / 100 \mathrm{~mL}$ citric acid (7.81 mM), 0.4 $\mu \mathrm{M}$ Sytox Green) were added to each well and left for 30 minutes in the dark (RT). Finally the solution was resuspended by soft tapping, transferred into a measuring tube and applied to flow cytometric analysis on the Partec PAS (Partec, Görlitz, Germany). 30,000 cells per sample were analysed using the software FloMax ${ }^{\oplus}$.

\section{Poly(ADP-ribosyl)ation}

The impact on poly(ADP-ribosyl)ation was determined as described previously [48]. Briefly, HeLa S3 cells were grown as monolayers in cell culture dishes equipped with coverslips (18 $\mathrm{mm}$ diameter) for $24 \mathrm{~h}$ and subsequently incubated with the particle suspensions or $\mathrm{CuCl}_{2}$ for $24 \mathrm{~h}$. Poly(ADP-ribosyl)ation was induced by treatment with $100 \mu \mathrm{M} \mathrm{H}_{2} \mathrm{O}_{2}$ for 5 minutes at $37^{\circ} \mathrm{C}$. As blind values, untreated cells as well as cells treated with the respective copper compounds in the absence of $\mathrm{H}_{2} \mathrm{O}_{2}$ were included and fluorescence intensities were substracted from those of copper plus $\mathrm{H}_{2} \mathrm{O}_{2}$-treated cells. Afterwards, coverslips were removed from the cell culture dishes, washed in ice-cold PBS and fixed in ice-cold $10 \%(\mathrm{w} / \mathrm{v})$ trichloroacetic acid for at least $15 \mathrm{~min}$. Afterwards, successive 5 minutes washings in ice-cold $70 \%$,
90\% and $100 \%$ ethanol took place. Air-dried coverslips were rehydrated in PBS and incubated with the monoclonal antibody $10 \mathrm{H}$ directed against poly(ADP-ribose) in blocking buffer (5\% skim milk powder in PBS) [49]. Incubation was carried out in a humid chamber at $37^{\circ} \mathrm{C}$ for $30 \mathrm{~min}$, followed by fourfold washing of the coverslips in PBS. The secondary, FITC-conjugated anti-mouse antibody (Sigma-Aldrich) in blocking buffer (dilution 1:30) was applied accordingly. Finally, coverslips were mounted on glass slides in Vectashield mounting medium containing DAPI. Fluorescence intensity was evaluated using a Zeiss Axio Imager.Z equipped with the software AxioVision version 4.8. The software allowed the simultaneous determination of the colocalised nuclear DAPI staining and nuclear poly(ADP-ribose) fluorescence. At least 100 cells were selected for quantification of FITC fluorescence.

\section{Bioavailability and intracellular distribution}

Soluble cytoplasmic and nuclear fractions of A549 cells were prepared using a method described previously [32]. Briefly, logarithmically growing A549 cells were incubated for the times indicated. The cells were trypsinized, collected in ice-cold PBS supplemented with 5\% FCS, washed twice with PBS and counted electronically for cell number and cell volume. All following steps were carried out on ice. $2 \times 10^{6}$ cells were allowed to swell in cell lysis buffer (0.01 M HEPES pH 7.9, $0.01 \mathrm{M} \mathrm{KCl}$, $0.0015 \mathrm{M} \mathrm{MgCl}_{2}, 0.3 \mathrm{M}$ saccharose, $0.0005 \mathrm{M}$ dithiothreitol (DTT), $0.0006 \mathrm{M}$ phenylmethanesulfonfluoride (PMSF), $0.0065 \mathrm{mM}$ Leupeptine) for 15 minutes before the addition of $25 \mu \mathrm{L} 10 \% \quad(\mathrm{v} / \mathrm{v})$ IGEPAL CA-630 (\#I3021, Fluka) in $\mathrm{H}_{2} \mathrm{O}$ for cell lysis. The mixture was vortexed for $10 \mathrm{~s}$ and the nuclei pelleted at $1500 \times \mathrm{g}$ $\left(15 \mathrm{~min}, 4^{\circ} \mathrm{C}\right)$. The supernatant contained the soluble cytoplasmic fraction. The nuclei-containing pellet was washed twice with cell lysis buffer to remove cytoplasmic residues. Subsequently, the volume of the nuclei was determined and the soluble nuclear content was extracted by treatment with the nuclear lysis buffer (0.01 M HEPES pH 7.9, 0.4 M KCl, $0.0015 \mathrm{M} \mathrm{MgCl}_{2}$, $15 \%$ (w/v) glycerol, 0.0005 M DTT, 0.0006 M PMSF, $0.0065 \mathrm{mM}$ Leupeptine) for 30 minutes on ice, in combination with repeated vortexing and subsequent centrifugation at $10000 \times \mathrm{g}\left(30 \mathrm{~min}, 4^{\circ} \mathrm{C}\right)$. The protein content was determined by the Bradford method using a ready to use solution (BioRad Laboratories $\mathrm{GmbH}$, München, Germany) and bovine serum albumine (BSA) (Merck KGAA, Darmstadt, Germany) as a standard [50]. Concentration of samples and chemical digestion were performed as described above. The copper content was determined using an ICP-MS 820 MS (Bruker Daltonics Inc., Billerica, USA). In case of results below the limit of detection, half this value was used to calculate mean values and standard deviation. Recoveries were determined in the respective 
matrix using AAS elemental standard solutions (Carl Roth AG) and reached 98\% (nuclear fraction) and 102\% (cytoplasmic fraction).

\section{Statistics}

Data were analysed for normal distribution and variance was calculated using Levene's test. Differences in the mean values were determined by using the unifactorial analysis of variance (ANOVA). In case of significance and variance homogeneity post-hoc Dunnett's- $T$ test was applied, in case of inhomogenic variances Dunnett's-T3 test. Significance testing of two groups was determined by Students' $t$-test. Software included Valoo 2.4 (analyticsoftware, Leer, Germany), SPSS 20 (IBM, Armonk, USA) as well as Microsoft Excel 2010 (Microsoft Deutschland GmbH, Unterschleißheim, Germany).

\begin{abstract}
Abbreviations
AAF: Artificial alveolar fluid; AlF: Apoptosis inducing factor; ALF: Artificial lysosomal fluid; BET: Brunauer-Emmett-Teller analysis; $\mathrm{CuCl}_{2}$ : Copper chloride; CUO MP: Copper oxide microparticles; CuO NP: Copper oxide nanoparticles; DMEM: Dulbecco's Modified Eagle Medium; DMEM/FCS: Dulbecco's Modified Eagle Medium supplemented with 10\% FCS; DLS: Dynamic light scattering; EDX: Energy-dispersive X-ray spectroscopy; EMA: Ethidium monoazide; FCS: Fetal calf serum; GF-AAS: Graphite furnace atomic absorption spectrometry; GSH: Glutathione; $\mathrm{H}_{2} \mathrm{O}$ : Ultrapure water; ICP-MS: Inductively coupled plasma mass spectrometry; PARP-1: Poly(ADP-ribose)polymerase-1; PBS: Phosphate buffered saline; ROS: Reactive oxygen species; RT: Room temperature; SEM: Scanning electron microscopy; TEM: Transmission electron microscopy; XRD: X-ray diffraction; ZP: Zeta potential.
\end{abstract}

\section{Competing interests}

The authors declare that they have no competing interests.

\section{Authors'contribution}

AH supervised and coordinated the research project and finalized the manuscript. The study design was performed by AS and AH. AS conducted the majority of the experiments, analysed the data and drafted the manuscript. JO and BW performed part of the experiments and were involved in the particle characterization by DLS. All of the authors have read and approved the final manuscript.

\section{Acknowledgements}

From the Karlsruhe Institute of Technology (KIT) we cordially thank: Dr. Thomas Bergfeldt and Cuc Ly from the department of "Technische Infrastruktur und Dienste - Ver- und Entsorgungsanlagen (TID-VEA)" for ICP-MS measurements, Volker Zibat from the Laboratory for Electron Microscopy for SEM and EDX measurements, Dr. Christel Adelhelm from the Insitute for Applied Material Physics (IAM) for the oxygen content measurements, Anna Schuch from the Institute of Process Engineering in Life Sciences for support with viscosity measurements and Dr. Mario Pauli from the "Institut für Hochfrequenztechnik und Elektronik (IHE)" for the dieelectricity constant measurements. Furthermore, we express our gratitude to Sören Selve from the "Zentraleinrichtung Elektronenmikroskopie" for the XRD and TEM measurements as well as Dr. Stephan Costabel from the Institute of Applied Geophysics, both located at the Technical University Berlin (TU Berlin), for the BET measurements. We also thank Prof. Alexander Bürkle from the University of Konstanz for providing the mouse myeloma cell line $10 \mathrm{H}$. This work was supported by grants from the Cluster of Excellence "Unifying Concepts in Catalysis", hosted by the Technical University Berlin, a Start-Up-Funding supplied by the Karlsruhe Institute of Technology (KIT) in the competence area "Applied Life Sciences (ALS)" and by the Deutsche Forschungsgemeinschaft (DFG), Exzellenzinitiative KIT and HA 2372/5-1.

Received: 31 July 2013 Accepted: 8 February 2014

Published: 13 February 2014

\section{References}

1. Linder MC: Copper and genomic stability in mammals. Mutat Res/Fundam Mol Mech Mutagen 2001, 475:141-152.

2. Rana SVS: Metals and apoptosis: recent developments. J Trace Elem Med Biol 2008, 22:262-284.

3. Festa RA, Thiele DJ: Copper: an essential metal in biology. Curr Biol 2011, 21:877-883.

4. Jomova K, Baros S, Valko M: Redox active metal-induced oxidative stress in biological systems. Transit Met Chem 2012, 37:127-134.

5. Hartwig A: Metal interaction with redox regulation: an integrating concept in metal carcinogenesis? Free Radic Biol Med 2013, 55:63-72.

6. Schwerdtle T, Hamann I, Jahnke G, Walter I, Richter C, Parsons JL, Dianov GL, Hartwig A: Impact of copper on the induction and repair of oxidative DNA damage, poly(ADP-ribosyl)ation and PARP-1 activity. Mol Nutr Food Res 2007, 51:201-210.

7. Reddy VP, Kumar AV, Swapna K, Rao KR: Copper oxide nanoparticlecatalyzed coupling of diaryl diselenide with aryl halides under ligandfree conditions. Org Lett 2009, 11:951-953.

8. Gabbay J, Borkow G, Mishal J, Magen E, Zatcoff R, Shemer-Avni Y: Copper oxide impregnated textiles with potent biocidal activities. J Ind Text 2006, 35:323-335.

9. Ben-Moshe T, Dror I, Berkowitz B: Oxidation of organic pollutants in aqueous solutions by nanosized copper oxide catalysts. Appl Catal B Environ 2009, 85:207-211.

10. Shah ID, Ruzzi PL, Schluter RB: Decomposition of cupric oxide using a reducing scavenger. United States Pat 1978, 4:080,430.

11. Nel AE, Madler L, Velegol D, Xia T, Hoek EMV, Somasundaran P, Klaessig F, Castranova V, Thompson M: Understanding biophysicochemical interactions at the nano-bio interface. Nat Mater 2009, 8:543-557.

12. Monopoli MP, Aberg C, Salvati A, Dawson KA: Biomolecular coronas provide the biological identity of nanosized materials. Nat Nano 2012, 7:779-786.

13. Sayes CM, Warheit DB: Characterization of nanomaterials for toxicity assessment. Wiley Interdiscip Rev Nanomed Nanobiotechnol 2009, 1:660-670.

14. Wang Y, Hodgkinson V, Zhu S, Weisman GA, Petris MJ: Advances in the understanding of mammalian copper transporters. Adv Nutr Res: Int Rev J 2011, 2:129-137.

15. Canton I, Battaglia G: Endocytosis at the nanoscale. Chem Soc Rev 2012, 41:2718-2739.

16. Hanagata N, Zhuang F, Connolly S, Li J, Ogawa N, Xu M: Molecular responses of human lung epithelial cells to the toxicity of copper oxide nanoparticles inferred from whole genome expression analysis. ACS nano 2011, 5:9326-9338

17. Wang Z, Li N, Zhao J, White JC, Qu P, Xing B: CuO nanoparticle interaction with human epithelial cells: cellular uptake, location, export, and genotoxicity. Chem Res Toxicol 2012, 25:1512-1521.

18. Cronholm P, Karlsson HL, Hedberg J, Lowe TA, Winnberg L, Elinn K, Wallinder 1O, Möller L: Intracellular uptake and toxicity of $\mathrm{Ag}$ and $\mathrm{CuO}$ nanoparticles: a comparison between nanoparticles and their corresponding metal ions. Small 2013, 9:970-982.

19. Karlsson HL, Cronholm P, Gustafsson J, Möller L: Copper oxide nanoparticles are highly toxic: a comparison between metal oxide nanoparticles and carbon nanotubes. Chem Res Toxicol 2008, 21:1726-1732.

20. Karlsson H, Gustafsson J, Cronholm P, Möller L: Size-dependent toxicity of metal oxide particles-a comparison between nano- and micrometer size. Toxicol Lett 2009, 188:112-118.

21. Midander K, Cronholm P, Karlsson HL, Elihn K, Möller L, Leygraf C, Wallinder IO: Surface characteristics, copper release, and toxicity of nano- and micrometer-sized copper and copper(II) oxide particles: a crossdisciplinary study. Small 2009, 5:389-399.

22. Song MF, Li YS, Kasai H, Kawai K: Metal nanoparticle-induced micronuclei and oxidative DNA damage in mice. J clin biochem nutr 2012, 50:211-216.

23. Perreault F, Melegari SP, da Costa $\mathrm{CH}$, de Oliveira Franco Rossetto AL, Popovic R, Matias WG: Genotoxic effects of copper oxide nanoparticles in Neuro 2A cell cultures. Sci Total Environ 2012, 441:117-124.

24. Di Bucchianico S, Fabbrizi MR, Misra SK, Valsami-Jones E, Berhanu D, Reip P, Bergamaschi E, Migliore L: Multiple cytotoxic and genotoxic effects induced in vitro by differently shaped copper oxide nanomaterials. Mutagenesis 2013, 28:287-299.

25. Semisch A, Hartwig A: Copper ions interfere with the reduction of the water soluble tetrazolium salt-8. Chem Res Toxicol 2014, epub ahead of print, doi:10.1021/tx400414c. 
26. Bryce SM, Bemis JC, Avlasevich SL, Dertinger SD: In vitro micronucleus assay scored by flow cytometry provides a comprehensive evaluation of cytogenetic damage and cytotoxicity. Mutat Res 2007, 630:78-91.

27. Berntsen P, Park CY, Rothen-Rutishauser B, Tsuda A, Sager TM, Molina RM, Donaghey TC, Alencar AM, Kasahara DI, Ericsson T, Millet EJ, Swenson J, Tschumperlin DJ, Butler JP, Brain JD, Fredberg JJ, Gehr P, Zhou EH: Biomechanical effects of environmental and engineered particles on human airway smooth muscle cells. J R Soc Interface 2010, 7(Suppl 3):331-340.

28. Studer AM, Limbach LK, Van Duc L, Krumeich F, Athanassiou EK, Gerber LC, Moch H, Stark WJ: Nanoparticle cytotoxicity depends on intracellular solubility: comparison of stabilized copper metal and degradable copper oxide nanoparticles. Toxicol Lett 2010, 197:169-174.

29. Huang C-C, Hwu JR, Su W-C, Shieh D-B, Tzeng Y, Yeh C-S: Surfactantassisted hollowing of Cu nanoparticles involving halide-induced corrosion-oxidation processes. Chem Eur J 2006, 12:3805-3810.

30. Seiffert JM, Baradez M-O, Nischwitz V, Lekishvili T, Goenaga-Infante H, Marshall D: Dynamic monitoring of metal oxide nanoparticle toxicity by label free impedance sensing. Chem Res Toxicol 2011, 25:140-152.

31. Lynch I, Dawson KA: Protein-nanoparticle interactions. Nano Today 2008, 3:40-47.

32. Schwerdtle T, Hartwig A: Bioavailability and genotoxicity of soluble and particulate nickel compounds in cultured human lung cells. Mater Werkst 2006, 37:521-525.

33. Ralle M, Huster D, Vogt S, Schirrmeister W, Burkhead JL, Capps TR, Gray L, Lai B, Maryon E, Lutsenko S: Wilson disease at a single cell level: intracellular copper trafficking activates compartment-specific responses in hepatocytes. J Biol Chem 2010, 285:30875-30883.

34. Fabisiak JP, Pearce LL, Borisenko GG, Tyhurina YY, Tyurin VA, Razzack J, Lazo JS, Pitt BR, Kagan VE: Bifunctional anti/prooxidant potential of metallothionein: redox signaling of copper binding and release. Antioxid Redox Signal 1999, 1:349-364

35. Bai P, Cantó $C$ : The role of PARP-1 and PARP-2 enzymes in metabolic regulation and disease. Cell Metab 2012, 16:290-295.

36. Krishnakumar R, Kraus WL: The PARP side of the nucleus: molecular actions, physiological outcomes, and clinical targets. Mol Cell 2010, 39:8-24.

37. Langelier M-F, Servent KM, Rogers EE, Pascal JM: A third zinc-binding domain of human poly(ADP-ribose) polymerase-1 coordinates DNAdependent enzyme activation. J Biol Chem 2008, 283:4105-4114.

38. Woodhouse BC, Dianov GL: Poly ADP-ribose polymerase-1: an international molecule of mystery. DNA Repair 2008, 7:1077-1086.

39. Rhun YL, Kirkland JB, Shah GM: Cellular responses to DNA damage in the absence of poly(ADP-ribose) polymerase. Biochem Biophys Res Commun 1998, 245:1-10.

40. Gradwohl G, de Murcia JM M, Molinete M, Simonin F, Koken M, Hoeijmakers $J \mathrm{H}$, de Murcia G: The second zinc-finger domain of poly(ADP-ribose) polymerase determines specificity for single-stranded breaks in DNA. Proc Natl Acad Sci 1990, 87:2990-2994.

41. Weibel A, Bouchet R, Boulc'h F, Knauth P: The big problem of small particles: a comparison of methods for determination of particle size in nanocrystalline anatase powders. Chem Mater 2005, 17:2378-2385.

42. Schulze C, Kroll A, Lehr C-M, Schäfer UF, Becker K, Schnekenburger J, Schulze Isfort C, Landsiedel R, Wohlleben W: Not ready to use overcoming pitfalls when dispersing nanoparticles in physiological media. Nanotoxicology 2008, 2:51-61.

43. Ladelfe PC, Czanderna AW, Biegen JR: Optical constants of cupric oxide from 450 to $800 \mathrm{m \mu}$. Thin Solid Films 1972, 10:403-411.

44. Brunauer S, Emmett PH, Teller E: Adsorption of gases in multimolecular layers. J Am Chem Soc 1938, 60:309-319.

45. Stopford W, Turner J, Cappellini D, Brock T: Bioaccessibility testing of cobalt compounds. J Environ Monit 2003, 5:675-680.

46. Midander K, Wallinder IO, Leygraf C: In vitro studies of copper release from powder particles in synthetic biological media. Environ Pollut 2007, 145:51-59.

47. Hartwig A, Klyszcz-Nasko H, Schlepegrell R, Beyersmann D: Cellular damage by ferric nitrilotriacetate and ferric citrate in V79 cells: interrelationship between lipid peroxidation, DNA strand breaks and sister-chromatid exchanges. Carcinogenesis 1993, 14:107-112.

48. Hartwig A, Pelzer A, Asmuss M, Bürkle A: Very low concentrations of arsenite suppress poly(ADP-ribosyl)ation in mammalian cells. Int J Cancer 2003, 104:1-6.
49. Kawamitsu $H$, Hoshino $H$, Okada H, Miwa M, Momoi H, Sugimura T: Monoclonal antibodies to poly(adenosine diphosphate ribose) recognize different structures. Biochemistry 1984, 23:3771-3777.

50. Bradford MM: A rapid and sensitive method for the quantitation of microgram quantities of protein utilizing the principle of protein-dye binding. Anal Biochem 1976, 72:248-254.

doi:10.1186/1743-8977-11-10

Cite this article as: Semisch et al:: Cytotoxicity and genotoxicity of nano - and microparticulate copper oxide: role of solubility and intracellular bioavailability. Particle and Fibre Toxicology 2014 11:10.

\section{Submit your next manuscript to BioMed Central and take full advantage of:}

- Convenient online submission

- Thorough peer review

- No space constraints or color figure charges

- Immediate publication on acceptance

- Inclusion in PubMed, CAS, Scopus and Google Scholar

- Research which is freely available for redistribution

Submit your manuscript at www.biomedcentral.com/submit
C) Biomed Central 